\title{
Pedagogical Approaches to "Down by the Riverside" and "Winnsboro Cotton Mill Blues" from North American Ballads by Frederic Rzewski
}

\author{
Sun Jung Lee \\ West Virginia University
}

Follow this and additional works at: https://researchrepository.wvu.edu/etd

\section{Recommended Citation}

Lee, Sun Jung, "Pedagogical Approaches to "Down by the Riverside" and "Winnsboro Cotton Mill Blues" from North American Ballads by Frederic Rzewski" (2013). Graduate Theses, Dissertations, and Problem Reports. 315.

https://researchrepository.wvu.edu/etd/315

This Dissertation is protected by copyright and/or related rights. It has been brought to you by the The Research Repository @ WVU with permission from the rights-holder(s). You are free to use this Dissertation in any way that is permitted by the copyright and related rights legislation that applies to your use. For other uses you must obtain permission from the rights-holder(s) directly, unless additional rights are indicated by a Creative Commons license in the record and/ or on the work itself. This Dissertation has been accepted for inclusion in WVU Graduate Theses, Dissertations, and Problem Reports collection by an authorized administrator of The Research Repository @ WVU.

For more information, please contact researchrepository@mail.wvu.edu. 


\title{
Pedagogical Approaches to "Down by the Riverside" and "Winnsboro Cotton Mill Blues" from North American Ballads by Frederic Rzewski
}

\author{
Sun Jung Lee
}

Research Project submitted to the College of Creative Arts at West Virginia University in partial fulfillment of the requirements

for the degree of

Doctor of Musical Arts in Piano Performance

\author{
Peter Amstutz, D.M.A., Chair \\ James Miltenberger, D.M.A. \\ William Haller, D.M.A. \\ Keith Jackson, D.M.A. \\ Ju-Hyeong Park, Sc.D.
}

School of Music

Morgantown, West Virginia

2013

Keywords: Frederic Rzewski, Down by the Riverside, Winnsboro Cotton Mill Blues, Pedagogy Copyright 2013 Sun Jung Lee 


\section{ABSTRACT}

\section{Pedagogical Approaches to "Down by the Riverside" and "Winnsboro Cotton Mill Blues" from North American Ballads by Frederic Rzewski}

\section{Sun Jung Lee}

"Down by the Riverside" and "Winnsboro Cotton Mill Blues," by Frederic Rzewski (1937 - present), are the third and fourth ballads, respectively, of the four that comprise his North American Ballads, completed in 1979. These two pieces are often performed together, without the first two ballads, perhaps because they seem to appeal to a wider audience, due to Rzewski's incorporation of familiar musical elements including folk music, jazz, blues, and improvisation.

These are impressive works which require a high level of skill from the pianist; this may also contribute to the frequency with which they are programmed for performance in recitals and competitions. Progressive music from our own time is often overlooked by performers because it can be farfetched and exclusive and can sometimes alienate listeners. However, the purpose of this research is in part to encourage pianists, particularly collegiate piano students, to perform contemporary works such as these, because they can appeal to most listeners.

This research project addresses the following crucial topics related to these works: First, there is a biographical discussion of the composer from his childhood through the 1970 s, when the North American Ballads appeared. Included in this biography is a discussion of the background of these pieces, the folk music incorporated in these works, and how this familiar material can appeal to the public. The primary focus of the research is a pedagogical discussion 
of "Down by the Riverside" and "Winnsboro Cotton Mill Blues," with suggestions by the author and others for learning and performing these works. 


\section{Table of Contents}

Chapter 1: Introduction ........................................................................ 1

Research Methodology ............................................................... 3

Review of Existing Literature .................................................... 4

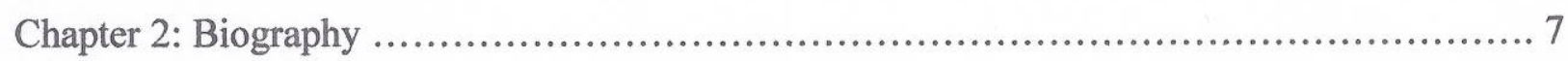

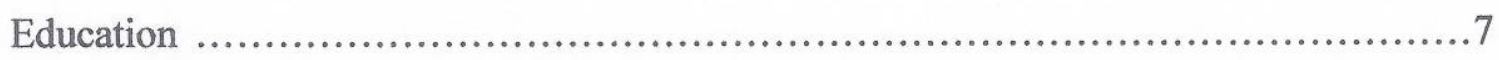

Influence of Avant-Garde Music and Colleagues .................................... 8

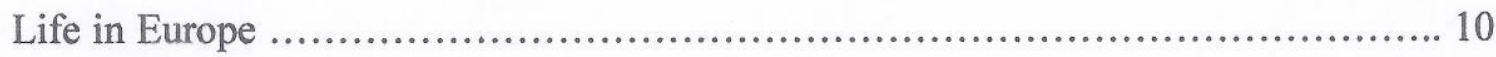

Back in New York, 1970s ...................................................... 13

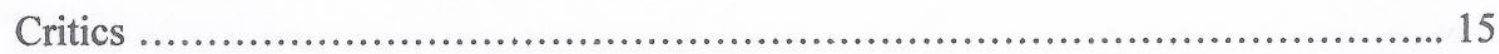

Historical Background on "Down by the Riverside" and "Winnsboro Cotton Mill Blues"................................................................................ 17

Chapter 3: "Down by the Riverside": The Learning Stage ...................................... 20

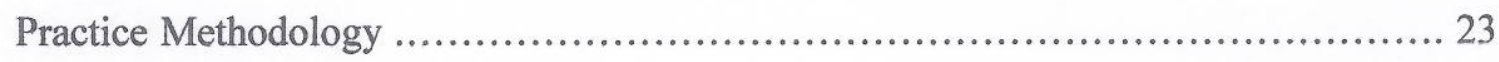

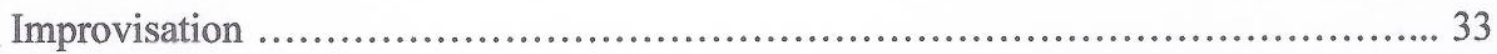

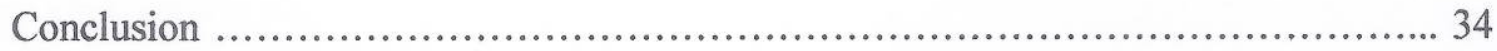

Chapter 4: "Winnsboro Cotton Mill Blues" .............................................. 35

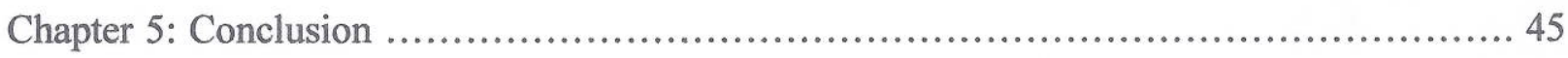




\section{List of Figures}

Figure 3.1: The original tune, Down by the Riverside

Figure 3.2: Rzewski "Down by the Riverside" (mm. 1-9) ................................ 24

Figure 3.3: Rzewski Down by the Riverside (mm. 14-15) .............................. 26

Figure 3.4: Rzewski Down by the Riverside (mm. 18-22) .............................. 27

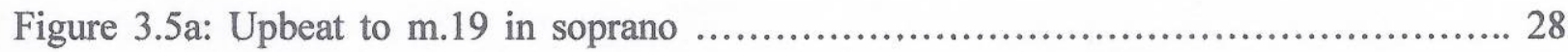

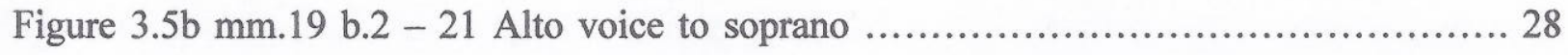

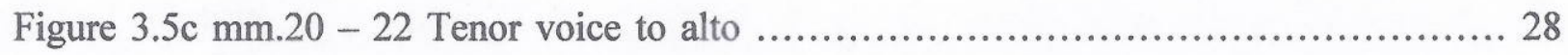

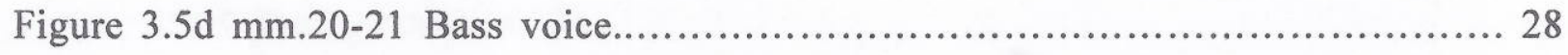

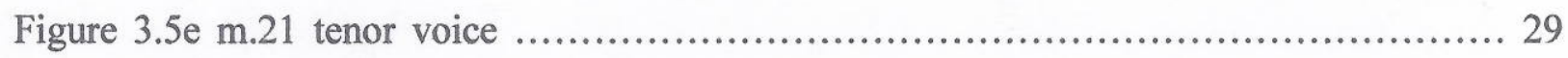

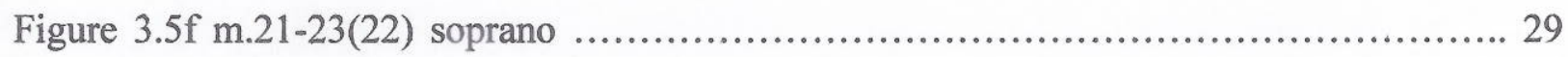

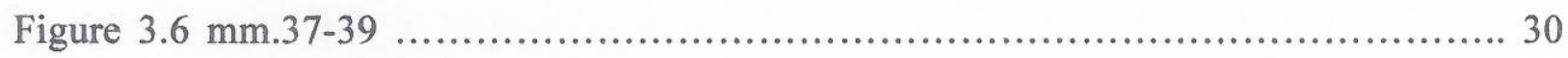

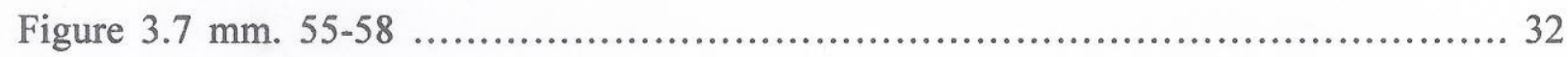

Figure 4.1 Winnsboro Cotton Mill Blues, mm.1-2 .......................................... 37

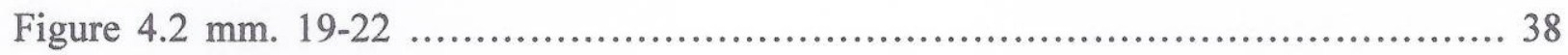

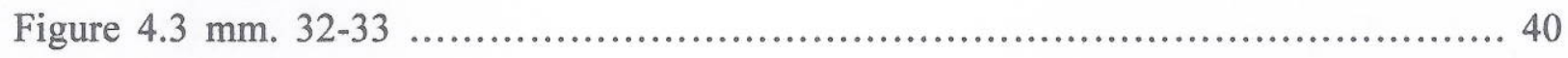

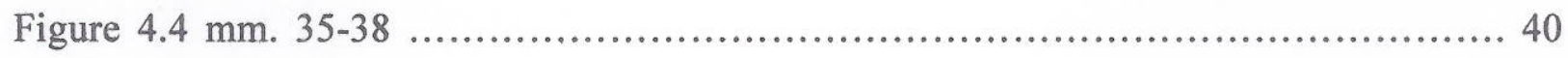

Figure 4.5 The Original Tune Winnsboro Cotton Mill Blues ............................ 41

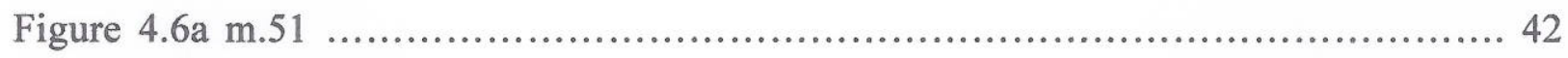

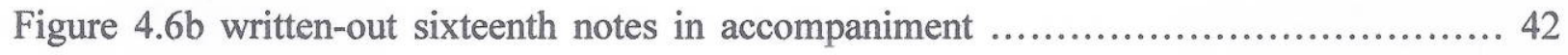

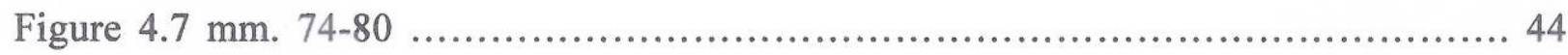

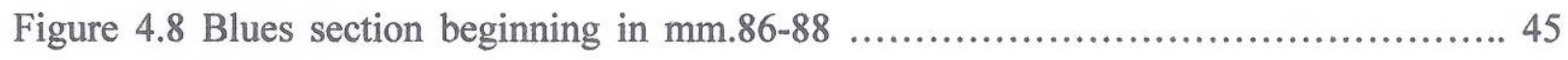

Figure 4.9 "I got the blues" from the original song in B-flat major ...................... 46 


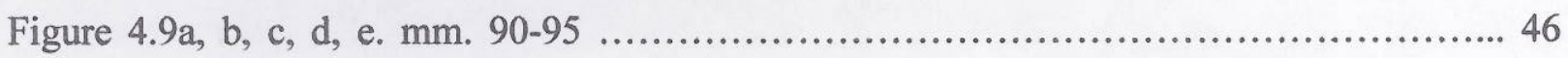

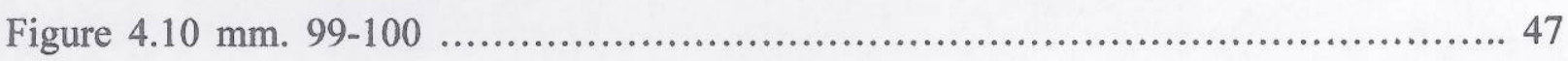

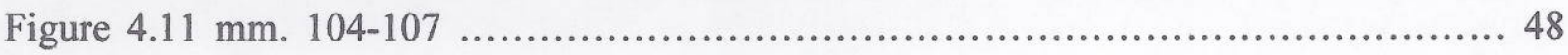




\section{Chapter 1}

Introduction

I have played the piano for over twenty years (as of November 2013) and have spent a large amount of time in academic environments: a performing arts school, a music center, a conservatory, and a university; as a result, I have been surrounded largely by classical musicians. As a musician, I listen to music on a daily basis: on the radio, via recordings, and through the attendance of recitals and concerts. However, I am surprised with the lack of interest in various styles of music among many who are not musicians. I feel that this lack of interest is often due to a lack of exposure to many styles of music, art music in particular. Many people find it fascinating to imagine having music as a profession and they carry fond memories of learning a musical instrument in their early childhood. But, they often discuss how this interest in music "got lost along the way."

Whether the audience has gradually turned from art music to pop culture, or people generally prefer other activities over attending concerts, the decline of classical music has been undeniable. ${ }^{1}$ However, I feel that programming works which can appeal to a larger audience can expose more people to classical music.

In this document, I will discuss two pieces which I believe will fit into this category. They are two of the four movements from North American Ballads by Frederic Rzewski (1937 present) entitled "Down by the Riverside" and "Winnsboro Cotton Mill Blues." These two pieces

${ }^{1}$ Greg Sandow, "Australia Talk" (lecture presented at the Australian classical music summit, Australia, July 12, 2010). In his keynote speech at the convention he lists the evidence of the decline of classical music in the United States including: the aging of the audience, declines in the number of classical radio stations, a decline in available recordings, the decline of concert ticket sales, the lack of funding, a lack of media coverage, and a report from the National Endowment for the Arts which reported a sharp decline in the percentage of adult Americans who go to classical performances. 
are more frequently performed than "Dreadful Memories" and "Which Side Are You On?," the

first two ballads of the set, largely because they seem to appeal to a wider audience.

This research topic is undertaken in the hope of encouraging more pianists to perform

twentieth-century music that speaks to a large audience who may not be music aficionados. In all

honesty, I also overlooked contemporary music for a long time, preferring eighteenth- and

nineteenth-century music because contemporary music often seemed farfetched and exclusive.

That attitude changed, at least partially, when I had a chance to hear Rzewski's piano pieces at a

colleague's recital over a decade ago. Hearing the performance and subsequently having the

opportunity to perform some of Rzewski's works created not only an appreciation for

contemporary music, but also an enjoyment of the positive feedback from the "non-music people"

in the audience. Sarah Cahill discusses the appeal of Rzewski's piano music in an article in

\section{Contemporary Music Review:}

Every few years, I teach a class on twentieth-century keyboard literature at the San Francisco Conservatory, for pianists who have little experience with contemporary music. It is always a pleasure to witness their great excitement at encountering The People United for the first time. Here is a piece that every young pianist waits for: a chance to give his or her classical technique a workout, to project a huge expressive range, to communicate directly to the audience, to dig into a composition as substantial as the Beethoven and Mozart sonatas, but, astonishingly, not much older than they are. Many young pianists shy away from contemporary music out of concern that composers have severed themselves from the classical tradition, so they are delighted to find out that Rzewski has embraced it. He is by far the most popular 20th-century composer with my students, and the fact that his music also attracts some of the finest pianists of our timeUrsula Oppens, Stephen Drury, Marc-Andre Hamelin, Anthony de Mare-is an added appeal. But when they respond so enthusiastically to his masterpieces-The People United, the North American Ballads, De Profundis, Mayn Yingele, the Sonata-I suggest that they seek out his many less performed piano pieces, freely available on the Werner Icking Archive website. ${ }^{2}$

\footnotetext{
${ }^{2}$ Sarah Cahill, "Some Piano Music by Frederic Rzewski," Contemporary Music Review, Vol. 29, No.6, Dec., 2010, p. 552.
} 


\section{Discussion of Research Methodology}

The research methodology for this document begins with a biographical discussion of Rzewski. For this biographical discussion, I have examined the available literature in order to provide an accurate account of Rzewski's musical development and career through the 1970's, when North American Ballads was written, in order to give pianists a better idea of the composer's creative agenda and his intentions for an accurate interpretation of the works.

The two pieces chosen for this study, "Down by the Riverside" and "Winnsboro Cotton Mill Blues" exhibit distinctive American flavor through advanced technical and musical requirements. Perhaps as a result, they have become popular among pianists for recitals, competitions, and music festivals. ${ }^{3}$ Important stylistic features of these works include contrapuntal techniques, the quotation of folk songs, improvisation, and extended techniques; all of these are significant traits of twentieth-century contemporary music.

This paper examines pedagogical approaches to "Down by the Riverside" and "Winnsboro Cotton Mill Blues" by discussing effective practice tools that the pianist can use in order to prepare for performance of these pieces. In addition, there is also a discussion of the initial reading stage of the learning process, identification of technically challenging passages, reflections upon performance-practice considerations, and practice suggestions for specific passages. Detailed practice suggestions, in the context of an esthetic point of view that seeks to respect the composer's intentions, are also provided.

\footnotetext{
${ }^{3}$ Nonesuch Journal, "Frederic Rzewski's $70^{\text {th }}$ Birthday Celebrated with Concerts at Gilmore Festival and Carnegie Hall," Nonesuch, April 27, 2008, http://www.nonesuch.com/journal/frederic-rzewskis-70th-birthdaycelebrated-with-concerts-at-gilmore-festival-and-carnegie-ha (accessed August 28, 2013) The renowned Gilmore Keyboard Festival, Kalamazoo, Michigan, featured two special concert events for Frederic Rzewski who performed a two-piano version of "Winnsboro Cotton Mill Blues" with Stephen Drury. In the same week, Rzewski also gave a concert in Carnegie Hall's Zankel Hall in New York, finishing his program with "Winnsboro Cotton Mill Blues" also with Drury.
} 


\section{Review of the Existing Literature}

As is the case for most living composers, many of the resources available for North American Ballads are dissertations and theses. Much of the literature includes portions of interviews with the composer. Sujin Kim's dissertation, which includes a nearly sixty-page-long transcribed interview, focuses on the performance practices of North American Ballads.

"Understanding Rzewski's North American Ballads: From the Composer to the Work, by Sujin Kim, focuses mainly on performance practice. Kim first reinforces the importance of the title, defines ballad as a musical genre, and discusses the use of quotation of folk music as the key element of the work as she traces the thematic development of the folk tune quoted. Kim transcribes a 60-page-long complete interview with Frederic Rzewski that provides a comprehensive and thorough discussion of the composer's thoughts and views regarding North American Ballads.

"The Keyboard Music of Frederic Anthony Rzewski with Special Emphasis on the North American Ballads, ${ }^{, 5}$ by Kim Hayashi, provides extensive information on the socio-economic background of the 1970s, a discussion of Rzewski's political beliefs, and a discussion of his compositional technique. Hayashi gives a significant amount of attention to Musica Elettronica Viva. However, her in-depth analysis of North American Ballads is the essence of her research. Hayashi also references her interview with the composer.

\footnotetext{
${ }^{4}$ Sujin Kim, Understanding Rzewski's North American Ballads: From the Composer to the Work (Saarbrücken: Verlag Dr. Müller, 2011).

${ }^{5}$ Kim Hayashi, "The Keyboard Music of Frederic Anthony Rzewski with Special Emphasis on the North American Ballads" (DMA diss., University of Arizona, 1995).
} 
"The solo piano music of Frederic Rzewski," by Ronald Lewis, sufficiently informs the reader about Rzewski's early education in music, made possible by his interview with the composer. Lewis categorizes Rzewski's solo piano compositions into three periods. North American Ballads falls into the second period, 1971-1979, along with No Place To Go But Around, People United Will Never Be Defeated, Four Pieces for Piano, and Squares. Lewis gives more significance to the historical background of the pieces along with brief analyses of each work.

The earliest dissertation written on Rzewski was "Paths to the New Romanticism: Aesthetic and Thought of the American Post-Avant-Garde as Exemplified in Selected Tonal Piano Music" by Gerald H. Groemer. One chapter of Groemer's dissertation is devoted to Rzewski's piano compositions of the 1970s. His previous chapters are given to George Rochberg, William Bolcom, and William Albright. Groemer views North American Ballads as being influenced by Charles Ives, with avant-garde flavor.

In the category of journal articles and essays, "Musical Reservata in Frederic Rzewski's 'North American Ballads,"' by Larry Bell and Andrea Olmstead, is published in The Musical Quarterly as one of the earliest articles written about Rzewski's music. This journal article provides a rather broad description of the music, alluding to its being reminiscent of Beethoven's Appassionata sonata, passacaglia techniques in Baroque opera, and $19^{\text {th- }}$ century piano writing. ${ }^{8}$

\footnotetext{
${ }^{6}$ Ronald Edwin Lewis, "The solo piano music of Frederic Rzewski" (DMA diss., The University of Oklahoma, 1992).

${ }^{7}$ Gerald H. Groemer, "Paths to the New Romanticism: Aesthetic and Thought of the American Post-AvantGarde as Exemplified in Selected Tonal Piano Music" (DMA diss., Peabody Conservatory of Music, 1984).

${ }^{8}$ Larry Bell and Andrea Olmstead, "Musical Reservata in Frederic Rzewski's 'North American Ballads'," The Musical Quarterly, Vol. 72, No. 4, 1986, p. 454.
} 
"The Pianist's Body at Work: Mediating Sound and Meaning in Frederic Rzewski's Winnsboro Cotton Mill Blues"9 by Kathryn Woodard provides the author's experience as a pianist performing Rzewski's piece. Her view reflects where this particular piece stands in social retrospect.

The final important article relating to this research is Tom Johnson's "Rzewski Talks," featured in The Village Voice. Initially, this interview with Rzewski appeared in the magazine entitled Wax Paper by Warner Brothers. However, Johnson, who started writing articles for avant-garde musicians and their concerts in New York in the 1970s, quoted Rzewski's interview from Wax Paper in "Rzewski Talks." This article was written in September, 1979, around the same time as North American Ballads; therefore, it provides the composer's most relevant thoughts and ideas on the pieces.

\footnotetext{
${ }^{9}$ Kathryn Woodard, "The Pianist's Body at Work: Mediating Sound and Meaning in Frederic Rzewski's Winnsboro Cotton Mill Blues." In Sonic Mediations: Body, Sound, Technology, edited by Carolyn Birdsall and Anthony Enns (New Castle upon Tyne: Cambridge Scholars, 2011), p.127-139.

${ }^{10}$ Tom Jonson, "Rzewski Talks," The Village Voice (New York), Vol. 24, September 3, 1979.
} 


\section{Chapter 2}

\section{Biography}

\section{Education}

Fredric Rzewski was born in Westfield, Massachusetts in 1938. He began playing the piano when he was five years of age. At the age of seven, he started taking piano lessons and began composition lessons at age ten with Charles Mackey, a local teacher who introduced the young Rzewski to the music of Schoenberg and Shostakovich. ${ }^{1}$ A gifted pianist, Rzewski began performing Beethoven's sonatas at the age of nine. ${ }^{2}$ Though he attended the Phillips Academy prep school in Andover, Massachusetts (over one hundred miles from his home in Westfield), he continued to return to Mackey for lessons. Mackey's influence during Rzewski's early childhood helped the composer embrace modern music. Furthermore, this expanded into steadfast dedication during his student years at Harvard University.

At the age of sixteen, Rzewski was admitted to Harvard where he studied counterpoint with Randall Thompson and composition and orchestration with Walter Piston. He graduated with a Bachelor of Arts degree in 1958. During his time at Harvard, Rzewski formed a strong musical foundation by extensively surveying piano literature, from Scarlatti and Frescobaldi to Beethoven and Liszt (though Rzewski was not fond of Liszt's compositions), and repeatedly listening to the string quartets of Beethoven, Bartók, and Schoenberg. ${ }^{3}$ Studying also with Piston at this time was David Behrman, whose friendship with Rzewski began during their time at the

\footnotetext{
1991), p. 14-16. 32.

${ }^{2}$ Cornelius Cardew, “A Note on Frederic Rzewski" The Musical Times, Vol. 117, No.1595, Jan. 1976, p.

${ }^{3}$ Lewis, p. 16.
}

${ }^{1}$ Ronald Edwin Lewis, "The solo piano music of Frederic Rzewski” (DMA diss., University of Oklahoma, 
Philips Academy. They respected Piston for his skilled craftsmanship with "abiding love of Bach," and a style of intelligence and grace. ${ }^{4}$ However, Rzewski was more interested in avantgarde music, especially those works based on the serialism of the second Viennese school. Rzewski was particularly interested in serialism, specifically Pierre Boulez's Le Marteau sans Maître, written in 1953, and Karlheinz Stockhausen's Gesang der Jünglinge, written in 1956. Rzewski's senior thesis dealt mainly with "the philosophical implications of serialism from Schoenberg through Stockhausen." It is quite obvious that Rzewski was well aware of new music because Gesang der Jünglinge was written in 1956 and he incorporated it in his thesis "The Reappearance of Isorhythm in Modern Music" in time to graduate in 1958.

\section{Influence of Avant-Garde Music and Colleagues}

Rzewski's strong interest in performing avant-garde music blossomed after he heard a performance of Pierre Boulez's Second Piano Sonata on a recital by pianist David Tudor when Rzewski was a second-year student at Harvard. Rzewski became acquainted with Tudor, who specialized in performing avant-garde music including that of John Cage, Morton Feldman, and Christian Wolff. This further inspired Rzewski to become an expert advocate of new music. At the time, most of the students and faculty members at Harvard were reluctant to explore new music. However, Wolff, Rzewski, and Behrman took charge of the Harvard Music Club and

\footnotetext{
${ }^{4}$ Howard Pollack, Harvard composers: essays on Walter Piston and his students: from Elliott Carter to Frederic Rzewski (New York, Scarecrow Press, 1992), p. 371.

${ }^{5}$ Pollack, p. 371.
} 
promoted the contemporary music of Karlheinz Stockhausen and Morton Feldman, as well as their own music, by giving recitals with guest artists including John Cage and David Tudor. ${ }^{6}$

With his interest in new music, Rzewski surrounded himself at Harvard with other likeminded composers, most notably David Behrman and Christian Wolff. Behrman's father was a distinguished playwright who wrote one of the first anti-fascist plays in America, and his uncle was the legendary violinist Jascha Heifetz. In the year prior to entering Harvard, a year after Rzewski's admission, Behrman studied the work of Henry Cowell, Edgar Varèse, Charles Ives, and the music that reflected radical left politics; ${ }^{7}$ presumably Behrman and Rzewski influenced each other.

Christian Wolff, with whom both Rzewski and Behrman associated while studying at Harvard, was a PhD candidate and an established avant-garde composer. As a result of their association Wolff and Rzewski "discovered one another to their mutual delight."

Wolff, who avoided Harvard music education as much as possible, was already composing chance music. The prevailing focus on neo-classicism at Harvard's music department did not impress Wolff or the two younger composers. Wolff, who also came from a musical family, believed not in imitating pre-existing music but rather in creating a distinctive change from existing earlier music. As he wrote:

I grew up in an environment saturated with standard classical music, and because of my father (who had played cello and whose father had been a professor of music in Germany and a composer, in the circle around Brahms) I was often in the company of distinguished musicians devoted exclusively to that music. It was only on hearing, more or less by accident, Bartók, Schoenberg, Berg, and Webern, and seeing the music of Varèse, Ives, and other composers, including Cage before I had met him, in the New Music Editions put out by Henry Cowell, that I thought, yes, I could and wanted to do that, too--not to

\footnotetext{
${ }^{6}$ Lewis, p. 17. Rzewski recalled.

${ }^{7}$ Pollack, p. 371.

${ }^{8}$ Ibid.
} 
imitate but to mark for myself a distinctive change from existing earlier music, classical and modern. My devotion to earlier music, though, continued, too, and was to extend back to late medieval and Renaissance music as well. Unlike Cage, Feldman, and Brown, I decided early on not to try to support myself through music. Strong interest in literature, especially poetry, starting with modernist poetry, somehow led me to study classics-Greek and Latin--and then to teach it. Musical activity would be continued as best I could. I was the only one of us who would go on to have a family, something I shared with two other younger composers, whom I met, one in 1956, the other in 1960, and with both of whom I became closely connected--Frederic Rzewski and Cornelius Cardew. (Rzewski and I have noticed how, once we had small children about, we developed structural schemes for our composing made up of collections of small units, such as could be concentrated on whenever, say, a quarter of half an hour might unexpectedly be free as a child suddenly fell asleep.

Wolff, Behrman, and Rzewski all shared their strong foundation in traditional repertoire, which then served as a tool for creating something new and different from the mainstream. Rzewski stated: "I felt that the avant-garde was the place for me. That's where I wanted to go, and everything that smacked of tradition or academic orthodoxy was something which I felt inclined to forget." 10 Through their friendship they encouraged each other and contributed to Rzewski's surpassing musicianship both as a pianist and a composer.

Rzewski's pursuit of avant-garde music led him to Princeton University where he studied with Roger Sessions and Milton Babbitt. While at Princeton, Rzewski also took an interest in philosophy and the Greek language, showing evidence of Wolff's influence on him.

\section{Life in Europe}

From 1960 to 1962, Rzewski was a Fulbright Scholar in Rome studying with Luigi

Dallapiccola, who was a leading composer of 12-tone music and a man with strong political

${ }^{9}$ Christian Wolff, "Experimental Music around 1950 and Some Consequences and Causes." American Music, Vol. 27, No.4 (Winter 2009); p.433-434.

${ }^{10}$ Lewis, p. 14. 
associations in Italy. ${ }^{11}$ In 1963 , Rzewski received a grant from the Ford Foundation's

Contemporary Music Project to study in Berlin with Elliot Carter, who was an American composer known for his emphasis on "rhythm, tempo contrasts, and dramatic characterization," 12 most notably metric modulation. These opportunities marked an important period of his life as Rzewski spent much of his life based in Europe. It was during this time that he established his reputation as a famous avant-garde pianist.

Rzewski's playing career began when he replaced David Tudor to give the premiere performance of Karlheinz Stockhausen's 1962 composition Klavierstück X in Palermo, Italy; he also performed this work in Munich, Germany, the following year. He also performed the same piece in England and successfully made himself known to English audiences at the BBC Invitation Concert. This led to his return to England at the invitation of Music Now with Musica Elettronica Viva, which Rzewski co-founded with Alvin Curran and Richard Teitelbaum. Rzewski became such a well-known pianist in Europe that his career was followed by such journals as La Rassegna Musicale and Ruch Muzyczny. ${ }^{13}$

Rzewski's 1966 founding of Musica Elettronica Viva (MEV) made a profound impact on his compositional style. The group was comprised of young American composers in Rome, including Alvin Curran, Richard Teitelbaum, and Allan Bryant. Their specific goal was to promote live electronic music, as the name indicated. However, from concert programs mainly consisting of fixed electronic music in the early years, MEV became more like an "improvised group activity" and "stage happening." Later on, Rzewski referred to this change as "the way of

${ }^{11}$ Kim Hayashi, "The Keyboard Music of Frederic Anthony Rzewski with Special Emphasis on the North American Ballads" (DMA diss., University of Arizona, 1995), p. 13.

${ }^{12}$ Kyle Gann, American Music in Twentieth Century (New York: Schirmer Books, 1997), p. 113.

${ }^{13}$ Pollack, p. 372. 
refinement and simplification of our basic idea: that of interpreting the moment, rather than constructing repeatable programmes."14

Improvisation in classical music was a concept that stemmed from MEV's slogan of "do your own thing." With improvisation being an essential element of $\mathrm{MEV}$, the group often collaborated with jazz musicians including Anthony Braxton and Cecil Taylor. Rzewski quickly came to believe that improvisation is an important aspect of playing classical music. According to Tom Johnson's 1979 article in "The Village Voice," Rzewski defined improvisation as "the flesh and blood of the music, the soul of the music" in comparison to the written parts as "the bones." Rzewski believes Beethoven's solo improvisations were found quintessential in attracting audiences of the nineteenth century. Johnson found Rzewski's rationale on improvisation a little excessive but concurred with the essence of what Rzewski was advocating-that both performers and composers should consider it more often. ${ }^{15}$ Therefore, despite the criticisms Rzewski received for adding more improvisation than what Beethoven notated on the score, he believed it was appropriate to do more improvisations than were notated. Rzewski's explanation for improvising when performing Beethoven's sonatas and concertos was explained during an interview with Sujin Kim:

Especially in the early piano literature of Beethoven, very often there is a fermata. Now, a fermata is usually interpreted as being held to sound for a while before continuing. But in many cases it means you are supposed to improvise a "little cadenza." Sometimes this is very obvious, but very often you hear a very strict interpretation of classical pieces where the music arrives at the fermata, there is a pause, and then the pianist continues with no improvisation ... I think in the early Beethoven sonatas there are many examples of where you should add something. ${ }^{16}$

\footnotetext{
${ }^{14}$ Hayashi, p. 21.

${ }^{15}$ Tom Jonson, "Rzewski Talks," Village Voice, Sept. 3, 1979, p. 72.

${ }^{16}$ Sujin Kim, Understanding Rzewski's North American Ballads (Saarbrücken: Verlag Dr. Müller GmbH \&
} Co. KG, 2011), p. 86. 
One of the most highly acclaimed contemporary pianists, Ursula Oppens, described Rzewski's use of improvisation as "a return to classical ideals," ${ }^{17}$ as it was prevalent in the performances of Mozart, Haydn, Beethoven, and Brahms in eighteenth- and nineteenth-century Europe. And

yet, as accomplished as Oppens is, even she admitted she wasn't comfortable playing this way. ${ }^{18}$ Many classical pianists share Oppens's view on improvisation in classical music and feel uncomfortable improvising.

\section{Back in New York, 1970s}

Rzewski's experience with MEV was groundbreaking and the group mounted a successful debut recital in New York, in February of 1970. The ideas and processes of the group gradually began changing New York's Downtown music scene, which had been widely viewed as post-Cagean, by promoting easy accessibility. The idea of "do your own thing" was prevalent in the Downtown scene. This was in contrast to the Uptown's post-Webern, high-art musicians who avoided any 'jazz' idiom. Rzewski's major concern during this time was, along with political music, "to integrate composition and improvisation in a way that benefited each" within rigorous structuralism. ${ }^{19}$ This was reflected in the list of his successful piano compositions written in the 1970s.

${ }^{17}$ Lewis, p. 20. Ursula Oppens interview by author, January $16,1991$.

${ }^{18}$ Seth Beckman, "The Traditional and the Avant-Garde in Late Twentieth-Century Music: A Study of Three Piano Compositions by Frederic Rzewski." (DMA diss., Ball State University, 1995), p. 40. Ursula Oppens interview by author, Nov. 24, 1993.

${ }^{19}$ Bernard Gendron, "Rzewski in New York (1971-1977)," Contemporary Music Review, Vol. 29, No.6 (Dec. 2010): p. 567. 
In 1971, Rzewski and his family moved to New York, where he worked as a freelance musician. During this time, Rzewski sought a new language that might enable even the most difficult and complex formal structure, with existing musical languages brought together, to be understood by a wide variety of people. The North American Ballads along with People United Will Never Be Defeated, Squares, and Four Pieces were based upon Rzewski's philosophy of appealing to a large group of listeners. ${ }^{20}$ These works were Rzewski's attempt to seek a wide variety of audiences, not to mention preserving his political ideology in North American Ballads, which include melodic references to songs of protest in "Down by the Riverside" and "Winnsboro Cotton Mill Blues." Rzewski's ideas on quoting a traditional melody with "timeless quality" were thoroughly explained in Tom Johnson's article, in reference to his piano composition, No Place To Go But Around, which incorporated the Italian militant song, Bandiera Rossa. Rzewski recalled:

For some reason, a traditional tune like that can be dealt with in a way which, say, a 12tone row cannot. Even if you don't know the tune, if it comes from a traditional context, it's like an old friend, a familiar face, it has a kind of timeless quality. You can hear a little bit of it, the beginning or the end, and you recognize it. It has a strong identity which a 12-tone row does not have. Bergson, the French philosopher, pointed out that melodies are like faces. You can hear just a bit of them, and if you know the tune you recognize it, just as you recognize a face. And therefore, he says, melodies exist outside of time. This timeless quality makes it possible to subject the melody to a variety of operations, sometimes some extremely distorting operations, still maintaining the identity of the original melody. ${ }^{21}$

\footnotetext{
${ }^{20}$ Hayashi, p. 16-17.

${ }^{21}$ Johnson, p. 72.
} 


\section{Critics}

Rzewski's seven-disk set of piano recordings for the Nonesuch label has received glowing reviews from critics, notably from John Warnaby ${ }^{22}$ and Andrew Clements. ${ }^{23}$ They both introduce Rzewski as one of the few outstanding American composers in the last fifty years, along with Elliot Carter. Clements writes in his newspaper article that Rzewski is "a fascinating, unclassifiable figure." Rzewski has to remain unclassifiable as he embraces many different techniques and styles with consummate skill. According to Warnaby, Rzewski's piano compositions exhibit the influence of both the "classical" and "romantic" traditions, with profound understanding of European heritage. In addition, he has developed jazz and improvisation technique through collaborations with Steve Lacy and Anthony Braxton, and adopted a percussive style from his awareness of postwar "modernism."

John Rockwell referred to Rzewski's "return to romanticism" with a political purpose as a hope to reach out to more people by using comfortable musical language. Rockwell gave credit to North American Ballads, which he felt were "genuinely gripping from a purely esthetic standpoint." On the other hand, he criticized the nature of political leftist composers such as Rzewski, Cornelius Cardew, and Christian Wolff as "condescending for political reasons." Rockwell mentioned an outcome that "none of them made much of an impact on the working classes, or on the third-world masses, or on China," and he suggested that the serious political composer must seek an idiom equivalent to Bob Dylan's "Blowin' in the Wind" to integrate into

\footnotetext{
${ }^{22}$ John Warnaby, review of Rzewski Plays Rzewski by Frederic Rzewski (piano), Tempo Vol. 57, No. 224 (Apr., 2003), 75-77.

${ }^{23}$ Andrew Clements, review of Rzewski Plays Rzewski, The Guardian (London), Nov. 1, 2002.
} 
art. $^{24}$ What Rockwell missed, however, was that Rzewski's music is intended for educated

people. Rzewski explains The People United Will Never Be Defeated!:

Being composed for traditional classical audiences-"people who are cultured, educated, intelligent, not especially dedicated to modern music but not prejudiced against it either. ${ }^{925}$

Bernard Gendron also addressed Rzewski's prevailing idea of the necessity of political

music, beyond entertainment, in the 1960 s and 1970s.

The primary function of political music is not to disseminate a didactic message to the masses in the hope of conversion, as it is oftentimes perceived, but to give expression to revolutionary longings or oppositional outrage among the progressive forces and the disaffected of society. Such was the way that successful political songs, such as 'Marseillaise,' 'Joe Hill,' or 'We Shall Overcome,' had their impact. ${ }^{26}$

Wolff and Oppens believed that Rzewski's music served as historical education for

listeners:

Like Mr. Wolff, Miss (Ursula) Oppens sees her performances of these works more as education than as a call to action. "Memories are very short," she says, "I hope that someday 'The People United' will be merely historical."27

Rzewski's versatility as a pianist has been long proven. His Carnegie Hall recital program

in 1972 consisted of his own composition October Music: Cold Weather Improvisation, J.S.

Bach's Have Mercy on Me Oh Lord, Pierre Boulez's Second Piano Sonata, and Christian Wolff's

Accompaniments. The New York Times review by Donal Henehan included the following:

A pianist who puts on one program Boulez's tightly organized Second Piano Sonata and a Dionysian improvisation of his own fertile invention knows where the outer limits of twentieth-century music lie. And when he plays both types of works as phenomenally well ... enlightenment and pleasure can only result.

${ }^{24}$ John Rockwell, All American Music (New York: Alfred Knopf, 1983), p. 89-95.

${ }^{25}$ Joshua Kosman, "Improvising with a pencil: the piano music of Frederic Rzewski," Piano \& Keyboard, March, 1993, p. 31.

${ }^{26}$ Gendron, p. 566.

1989.

${ }^{27}$ Heidi Waleson, "Anthems and Troubadours that Stirred Crowds to Protest," New York Times, Sep. 10, 
The piano is an essential tool for Rzewski as a composer. Lewis quotes Rzewski as saying "I learned to compose by playing the piano," 28

\section{"Down by the Riverside" \& "Winnsboro Cotton Mill Blues"}

North American Ballads, completed in 1979, was a project Rzewski started at the request of a former "house pianist" with the New York Philharmonic Orchestra, Paul Jacobs, who wanted Rzewski to write a piece in American flavor. ${ }^{29}$ Comprised of four pieces based upon American traditional and protest songs, they served the same purpose as a brilliant set of 36 variations written for solo piano, The People United Will Never Be Defeated, written in 1976, which incorporated the Chilean protest song iEl Pueblo Unido Jamás Será Vencido! and No Place to Go But Around, quoting the Italian Bandiera Rossa. The first and the second ballads are based upon protest songs related to a coal miner's strike in 1930s, those pieces being "Dreadful Memories" and "Which Side Are You On?" The first ballad was based upon a hymn tune entitled "Precious Memories," a work attributed to Aunt Molly Jackson, who witnessed thirtyseven children's deaths as a result of the 1932 coal miner's strike. The second ballad, as indicated by the title, quoted the protest song "Which Side Are You On?" written by Florence Reece.

Rzewski recalls his association with Pete Seeger during his stay in New York in the early 1970s. A folk singer and song writer with intense social awareness, Seeger greatly influenced Rzewski, who had then joined the Musician's Action Collective, whose purpose was to give socially and politically relevant concerts. After taking Seeger's advice, Rzewski concluded that

\footnotetext{
${ }^{28}$ Lewis, p. 14.

${ }^{29}$ Beckman, p. 101. Rzewski interview by author, Feb. 24-26, 1994.
} 
modeling after J.S. Bach's periodic use of melodies would include more audience participation, which Seeger considered essential in all concerts. North American Ballads specifically follows Bach's use of Lutheran hymns in his chorale preludes for organ and uses contrapuntal techniques such as augmentation, diminution, transposition, and compressions. ${ }^{30}$ Rzewski's most useful tools were gained during his education and training in institutions. Howard Pollack wrote "the contrapuntal concerns of their [Rzewski's and Behrman's] mature work, for instance, showed a respect and understanding of Bach, nurtured under Piston's guidance. ${ }^{931}$

The third ballad, "Down by the Riverside," also known as "I Ain't Going to Study War No More," was written for The Festival of Political Song held biennially in Berlin. ${ }^{32}$ Because of the recent war, Vietnam was a featured country at the 1979 Festival of Political Song which Rzewski attended; this influenced Rzewski's choice of this particular tune, which was often sung by Americans during the 1960s and 1970s in protest of the Vietnam War. According to Hershberger, this African-American spiritual's specific origin is unknown, but can be traced back to the nineteenth century ${ }^{33}$ In the original key of D major, Rzewski introduces a complete statement of the tune in the same key; this statement lasts ten measures before he turns it into a highly contrapuntal texture.

"Winnsboro Cotton Mill Blues," the song used in the last of Rzewski's set, was first recorded by Bill Wolff in 1939 and again by Pete Seeger much later in 1992 for his album American Industrial Ballads. Although the tune's origin is unknown, Hershberger remarks that

\footnotetext{
${ }^{30}$ Rzewski Plays Rzewski, Piano Works, 1975-1999, Nonesuch 79623-2, 2002.

${ }^{31}$ Pollack, p. 394.

${ }^{32}$ Lewis, p. 76.

${ }^{33}$ Monica Hershberger, "Frederic Rzewski's North American Ballads: Looking Back to the Radical Politics of 1930s America" (master's thesis, Michigan State University, 2011), p. 43.
} 
the text depicts textile mills in North Carolina, most likely after the nationwide 1934 General Strike. ${ }^{34}$ In composing this piece Rzewski was inspired by the movie Norma Rae, named for the factory worker who led the labor-union rally in the movie. Stylistically different from the rest of the three ballads, "Winnsboro Cotton Mill Blues" produces a tour de force sound effect by simulating machinery at the piano.

${ }^{34}$ Hershberger, p. 51. 


\section{Chapter 3}

\section{"Down by the Riverside"}

\section{The Learning Stage}

In an interview with Sujin Kim, Rzewski strongly suggests that the pianist listen to "the

original songs" ${ }^{1}$ in the beginning stages of learning this piece. Knowing the original source material, which appears below as Figure 3.1, is essential to understanding Rzewski's composition based on that material.

${ }^{1}$ Sujin Kim. Interview with Rzewski; how to approach North American Ballads, p. 69. Rzewski explains these folk tunes are not just folk music but they are originally religious hymns. 
Figure 3.1 The original tune, Down by the Riverside as shown by Cornett-Murtada. ${ }^{2}$

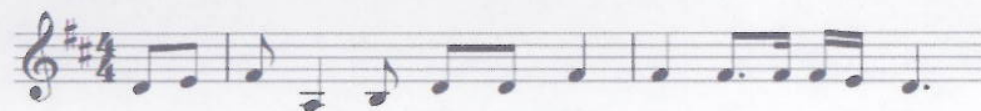

3 Gon na lay down my sword and shield, down by the ri-ver-side,
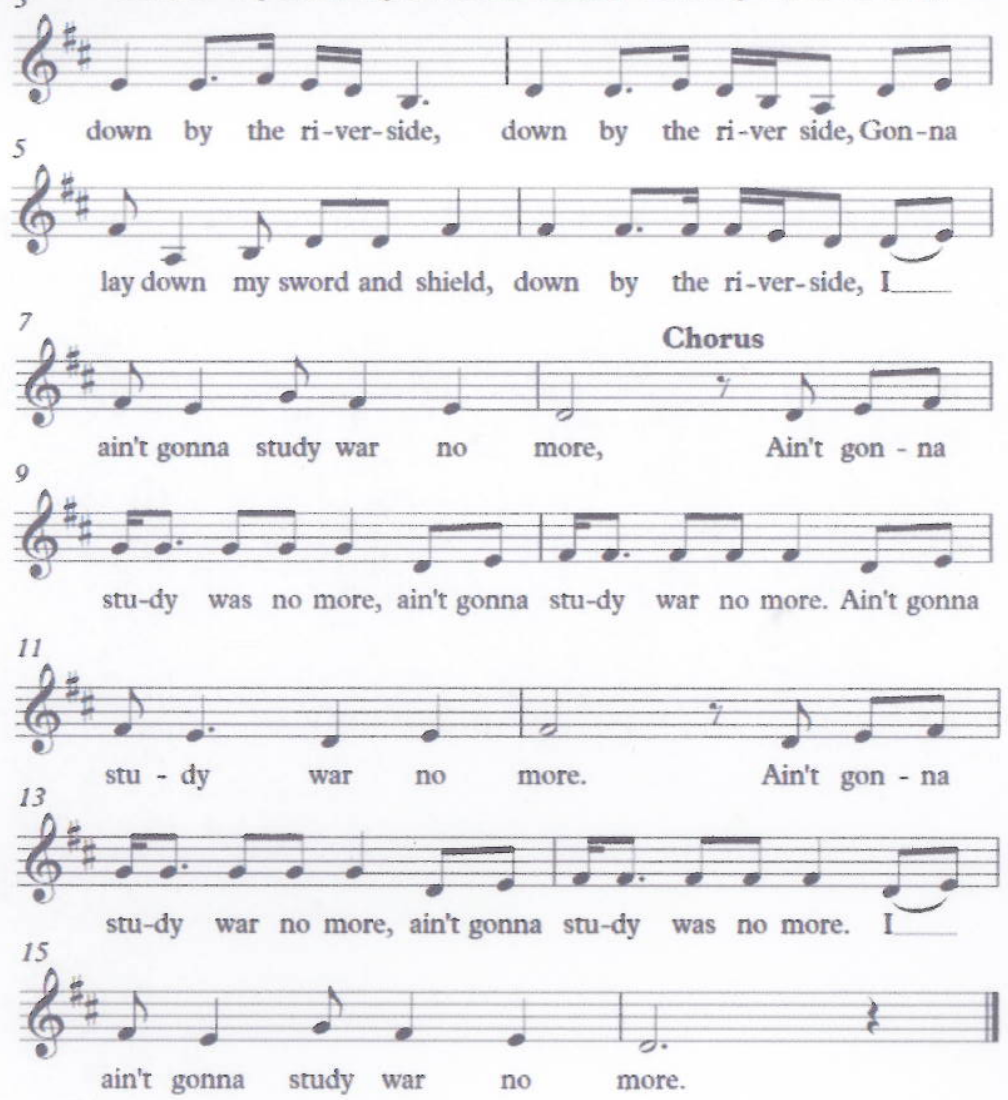

Of course, there are many ways to begin learning a new piece and there is no single "best way to start." Choice of practice tools can and should vary significantly, depending on the style of the piece, its technical demands, and the preferences, learning style, and relative strengths of the individual pianist.

${ }^{2}$ Vanessa Cornett-Murtada, "Quotation, Revolution, and American Culture: The Use of Folk Tunes and the Influence of Charles Ives in Frederic Rzewski's North American Ballads for Solo Piano." (DMA diss., The University of North Carolina at Greensboro, 2004), p. 72. 
In his book, The Pianist's Problems, William Newman recommends that the pianist find a good recording of the piece and critically listen to it while following the score; ${ }^{3}$ this helps one obtain a better grasp of the piece as a whole. Karl Leimer, who was a teacher of Walter Gieseking, emphasizes detailed analysis of the score, which involves studying away from the instrument. Leimer believes that "visualizing" the score before beginning to practice at the instrument enables accurate knowledge of the piece and that therefore it is an "indispensable necessity" when training the ear. ${ }^{4}$ To some extent, I agree with Leimer's view. ${ }^{5}$ No reading, listening, and studying, however, would compare to actually playing the piece, as Ellen Thompson writes in Teaching and Understanding Contemporary Piano Music. ${ }^{6}$ Newman also emphasizes the importance of accurately learning the notes, rhythms, and dynamics as a whole from the very beginning. I concur with Newman and also suggest noting any markings by the composer.

After becoming familiar with the score, I suggest playing through the entire piece and then practicing each section slowly. The purpose of playing through the piece is not only to get an overview of the piece, but also to detect certain areas which seem technically more challenging and/or musically ambiguous. The pianist should make note of such passages in order to focus on them in later practice sessions. However, some technical sections can be mastered quickly as one plays through the piece a few times.

\footnotetext{
${ }^{3}$ William S. Newman, The Pianist's Problems (New York: Harper \& Brothers, 1956), p. 134.

${ }^{4}$ Walter Gieseking and Karl Leimer, Piano Technique (New York: Dover, 1972), p. 11.

${ }^{5}$ Stewart Gordon. "Other Twentieth-Century Pedagogy" The Well-Tempered Keyboard Teacher, ed. M. Uszler, S. Gordon, E. Mach. (New York: Schirmer: 1991), p. 344. Gordon finds the degree of Karl Leimer's approach in detailed analysis rather unusual. Leimer's book Piano Technique indicates such detailed analysis, away from piano, leads to clarity, resulting in faster learning.

${ }^{6}$ Ellen Thompson, preface to Teaching and Understanding Contemporary Piano Music (Kjos West: San Diego, 1976).
} 
Breaking down the piece into smaller sections constitutes another important consideration during the initial stages of learning. Unlike sonata-allegro movements, in which pianists are accustomed to labeling the exposition, development, and recapitulation, Rzewski's "Down by the Riverside" and "Winnsboro Cotton Mill Blues" do not have such a clear-cut formal structure. Considerable knowledge is required for a teacher to guide a student in analyzing the structure of these particular pieces. "Down by the Riverside" consists of five clearly distinguished sections, each of which can be recognized visually as well as aurally. Section A lasts from mm.1-18, section B from mm.19-36, section C from mm.37-66, section D from mm.67-82, and section $\mathrm{E}$ from $\mathrm{mm} .83-90$.

Difficulties in reading the highly contrapuntal sections are predictable. Therefore, the pianist is expected to start this piece at a tempo in which the most difficult passages or sections are manageable. This author recommends the initial tempo of $d=40$; however, the pianist may proceed at a slower tempo if the contrapuntal sections at $\mathrm{B}$ and $\mathrm{C}$ prove unplayable. Even more important than the speed of the initial tempo is that a student should maintain the same tempo throughout these sections and consistently count the quarter-note beats to ensure that all of the sixteenth notes are aligned. At this point in the learning process, pedaling is for the most part to be avoided in order to provide the pianist with a clear idea of the notes and rhythms. However, the pedal is useful in the initial reading so that a student can hear and understand the disjunct notes and wide leaps of the music.

\section{Practice Methodology}

Having the piece broken down into five smaller sections, the pianist should come up with a strategy for practicing each one. The original spiritual as a whole is introduced in section 
A. The left hand plays a pleasantly inviting gospel-style accompaniment, which depicts water, under the jazzy melody of the right hand (Figure 3.2). The tempo is marked at $d=80 / 88$, but Kim reports that Rzewski himself suggested a slower tempo, around $d=60 .^{7}$ The material in this section is presented in the original key and meter of the spiritual, that is, in D major and in $4 / 4$ time.

Figure 3.2 Rzewski Down by the Riverside, mm.1-9
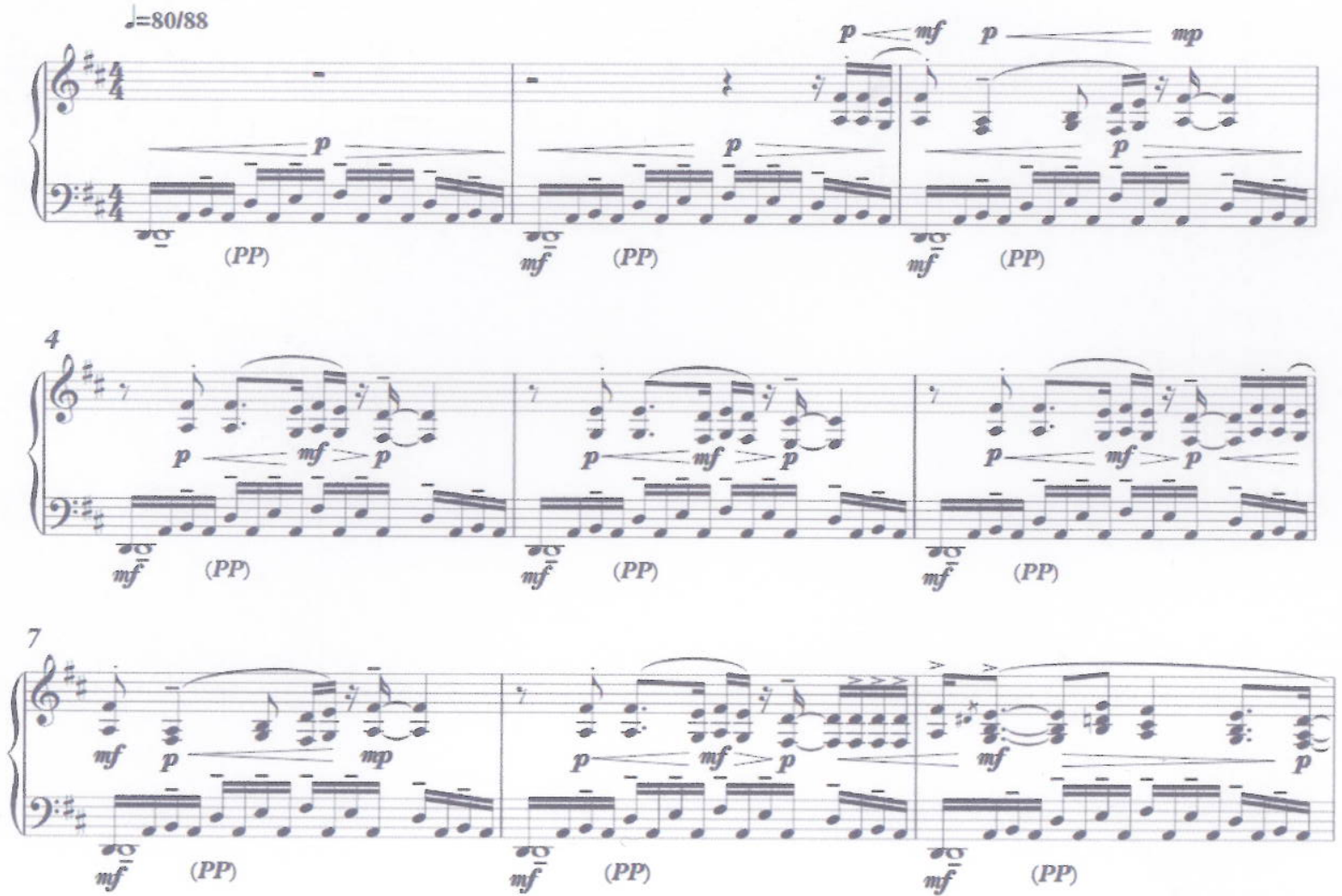

(C) Rzewski "Down by the Riverside" from NORTH AMERICAN BALLADS. Copyright 1979 by Zen-On Music Co. Ltd. All Rights Reserved. Used by permission of European American Music Distributos Company, sole U.S. and Canadian agent for Zen-On Music Company Limited.

\footnotetext{
${ }^{7}$ Sujin Kim, p.95. Rzewski interview by author.
} 
The left-hand ostinato continues throughout section A, while the right-hand melody grows from piano to forte with added notes and an octave shift in $\mathrm{m}$. 14. The opening measure of the left hand alone creates an image of the river, and the pianist is encouraged to play the sixteenth-notes with mild swing, which naturally brings out the moving notes, marked tenuto by the composer (Figure 3.2). ${ }^{8}$ The player should avoid using the same rubato at every downbeat. This passage requires control of the left thumb in order to create a gentle wave effect. Hayashi writes that the notes marked tenuto outline a melodic line of the previous ballad, "Which Side Are You On?", hence adding unification to the set. ${ }^{9}$ However, Hayashi also writes that "this quotation is not audible to the ear." Rzewski's intention to unify the second ballad and the third ballad with those few notes inaudible to the ear would be less likely.

The right-hand melody, which begins in parallel sixths, requires consistency, with the soprano voice being prominent while still providing an accompaniment from the lower voices. Voicing becomes challenging in $\mathrm{m} .14$ when seventh chords with a doubled octave appear (Figure 3.3). One should maintain relaxed fingers, lean on the fifth finger, and keep a flexible wrist in order to play these dense chords effectively.

\footnotetext{
${ }^{8}$ CDA 79623-2 Rzewski Play Rzewski. Nonesuch: Brussels: 2002. The composer swings the $16^{\text {th }}$-notes.

${ }^{9}$ Kim Hayashi, p. 117.
} 
Figure 3.3 Rzewski Down by the Riverside, mm. 14-15

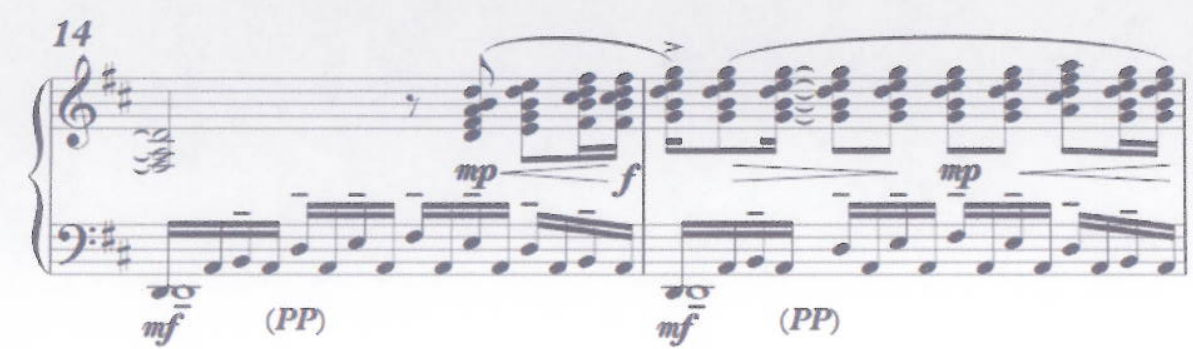

(C) Rzewski "Down by the Riverside" from NORTH AMERICAN BALLADS. Copyright 1979 by Zen-On Music Co. Ltd. All Rights Reserved. Used by permission of European American Music Distributos Company, sole U.S. and Canadian agent for Zen-On Music Company Limited.

The B section, mm. 19-36, is marked Lo stesso tempo, ma con rubato e flessibile; quasi uma [most likely intending "una"] fantasia, which translates to keep the same tempo, however with rubato and flexibility; almost like a fantasia. This section includes highly contrapuntal materials, including fragmentation and augmentation. Redistributing material between the hands is also required to accommodate disjunct passages. For example, the pitch $\mathrm{F}$ played by the left hand on the second half of beat three in the alto voice, m. 19, is part of a melodic fragment which is played by the right hand; therefore a pianist needs to be sure that the left thumb matches the preceding notes. The same technique applies to the right hand thumb playing the pitch $\mathrm{G}$ on the second half of beat two in the tenor voice, $\mathrm{m}$. 20. It requires attentive listening to bring out the $\mathrm{G}$ just enough to continue the line of the melodic fragment. This is particularly challenging because the right thumb crosses over the left thumb, which is a half-step down on A-flat (Figure 3.4).

Tracing each motivic line is very important, as this holds everything together in this highly contrapuntal section. The motivic rhythm $\| \bar{\cdots} \therefore . \therefore \overline{10}$ is prevalent, presented in different voices and keys. Such motivic obsession, as Larry Bell calls it, ${ }^{10}$ is

\footnotetext{
${ }^{10}$ Larry Bell and Andrea Olmstead, "Musical Reservata in Frederic Rzewski's 'North American Ballads'," The Musical Quarterly, Vol. 72, No. 4, 1986, p. 450.
} 
exhibited in the following: the soprano voice in D-major, $\mathrm{m} .18$ (Figure $3.5 \mathrm{a}$ ), the alto voice in Bb-major, mm. 19-21 (Figure 3.5b), the tenor voice, first in $\mathrm{Bb}$ major, then in $\mathrm{D}$ major, $\mathrm{mm}$. 2022 (Figure 3.5c), the bass voice in G-major, mm. 20-21 (Figure 3.5d), the tenor voice in Bbmajor, mm. 21-22 (Figure 3.5e), and the soprano voice, first in E-flat major, then in A-flat major, mm. 21-23 (Figure 3.5f). Rzewski's extensive use of stretto foreshadows the complexity of the piece with the distinctive rhythmic figure of the motivic line used abundantly; yet each derivative is clearly audible. The intricacy of this section is revealed by each voice crossing freely over to other voices. A close comparison of this four-measure passage (Figure 3.4) and each traced thematic voice within those measures (Figure 3.5) shows the complexity of Rzewski's contrapuntal manipulation within this piece. Such analysis helps to train the ears, the fingers, and the mind of the pianist, with the goal of being able to reveal as many voices as possible in performance.

Figure 3.4 Rzewski Down by the Riverside, mm. 18-22
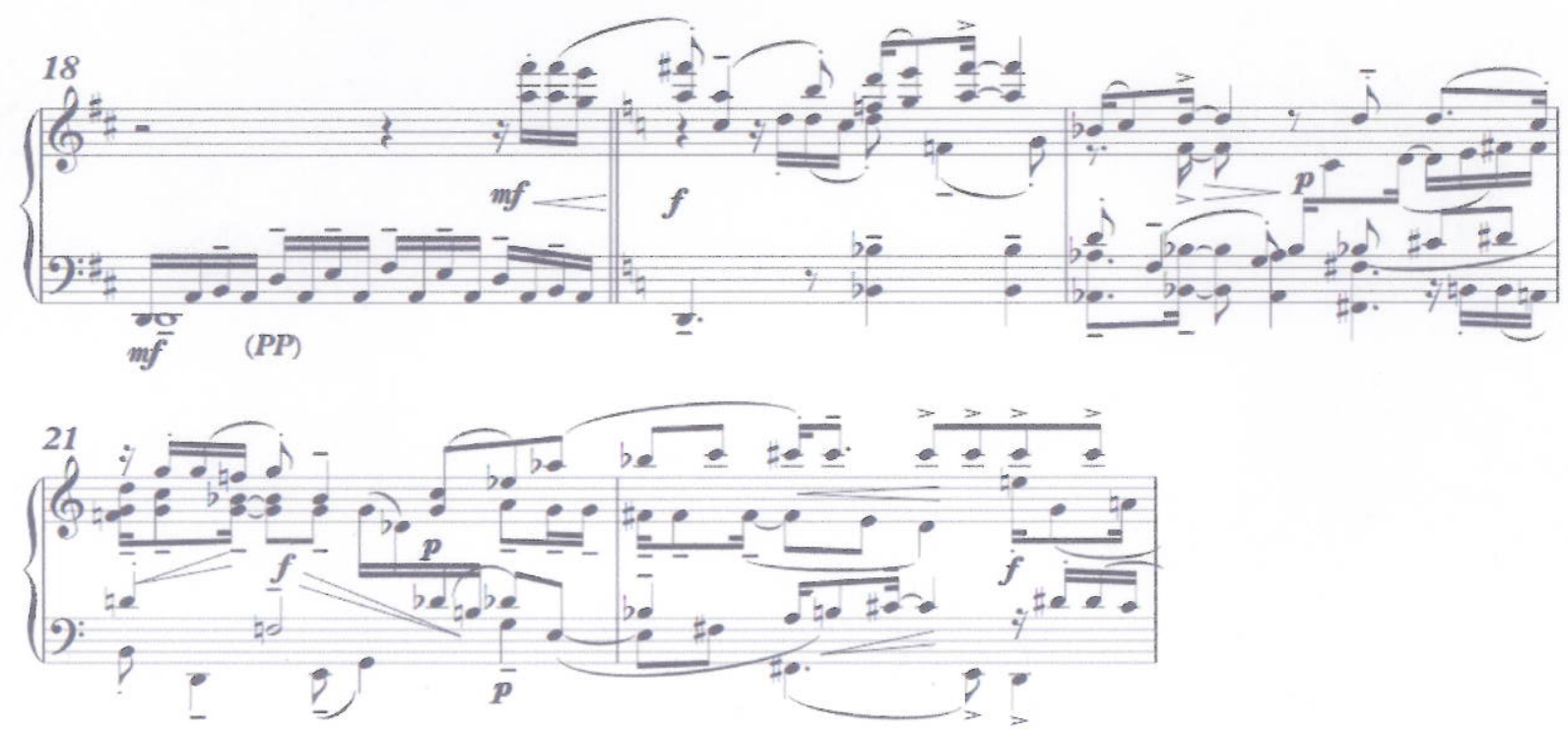
(C) Rzewski "Down by the Riverside" from NORTH AMERICAN BALLADS. Copyright 1979 by Zen-On Music Co. Ltd. All Rights Reserved. Used by permission of European American Music Distributos Company, sole U.S. and Canadian agent for Zen-On Music Company Limited.

Figure 3.5a Upbeat to $\mathrm{m} .19$ in soprano voice

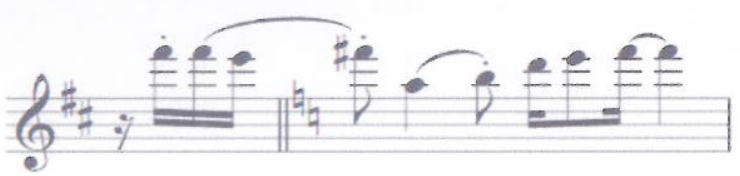

(C) Rzewski "Down by the Riverside" from NORTH AMERICAN BALLADS. Copyright 1979 by Zen-On Music Co. Ltd. All Rights Reserved. Used by permission of European American Music Distributos Company, sole U.S. and Canadian agent for Zen-On Music Company Limited.

Figure $3.5 \mathrm{~b} \mathrm{~m} .19$ (beat 2)-m.21. Alto voice to soprano voice

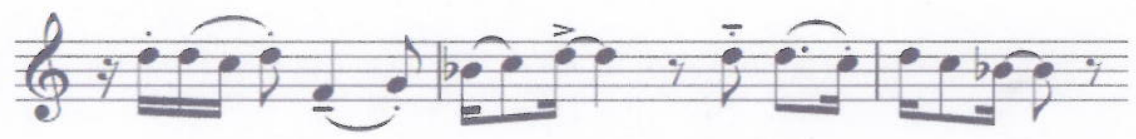

(C) Rzewski "Down by the Riverside" from NORTH AMERICAN BALLADS. Copyright 1979 by Zen-On Music Co. Ltd. All Rights Reserved. Used by permission of European American Music Distributos Company, sole U.S. and Canadian agent for Zen-On Music Company Limited.

Figure $3.5 \mathrm{c} \mathrm{mm} .20-22$. Tenor voice to alto voice

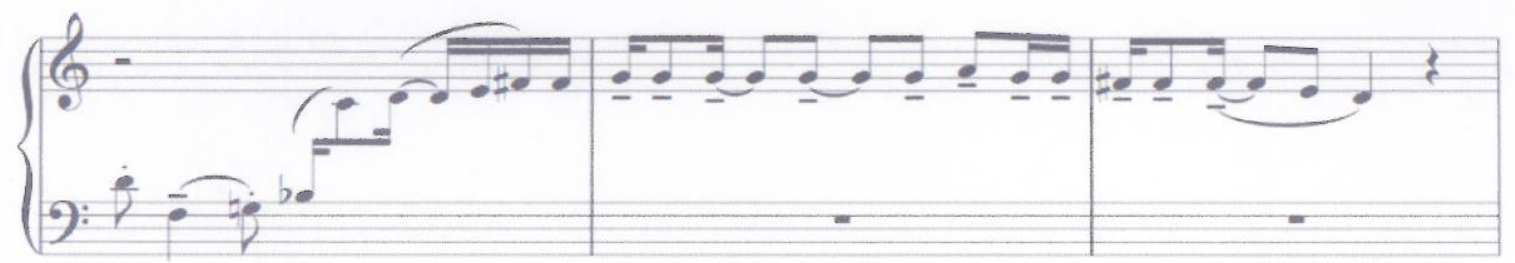

(C) Rzewski "Down by the Riverside" from NORTH AMERICAN BALLADS. Copyright 1979 by Zen-On Music Co. Ltd. All Rights Reserved. Used by permission of European American Music Distributos Company, sole U.S. and Canadian agent for Zen-On Music Company Limited.

Figure $3.5 \mathrm{~d} \mathrm{~mm} .20-21$ bass voice

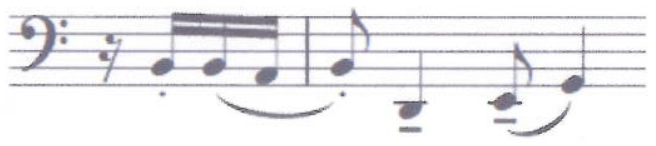


(C) Rzewski "Down by the Riverside" from NORTH AMERICAN BALLADS. Copyright 1979 by Zen-On Music Co. Ltd. All Rights Reserved. Used by permission of European American Music Distributos Company, sole U.S. and Canadian agent for Zen-On Music Company Limited.

Figure $3.5 \mathrm{e} \mathrm{m} .21$ tenor voice

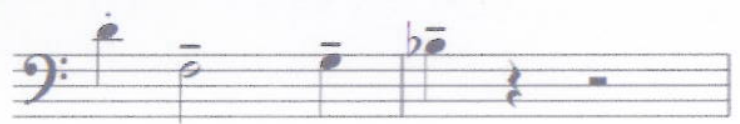

(C) Rzewski "Down by the Riverside" from NORTH AMERICAN BALLADS. Copyright 1979 by Zen-On Music Co. Ltd. All Rights Reserved. Used by permission of European American Music Distributos Company, sole U.S. and Canadian agent for Zen-On Music Company Limited.

Figure $3.5 \mathrm{fmm} .21-22(23)$ soprano voice

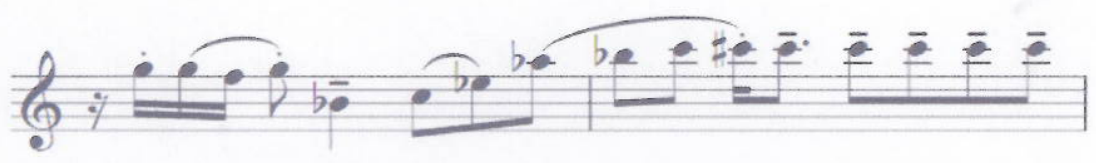

(C) Rzewski "Down by the Riverside" from NORTH AMERICAN BALLADS. Copyright 1979 by Zen-On Music Co. Ltd. All Rights Reserved. Used by permission of European American Music Distributos Company, sole U.S. and Canadian agent for Zen-On Music Company Limited.

After recognizing each motivic fragment, the pianist should try playing the notes of the upper register using both hands; this enables the student to hear the motivic lines more clearly. Trying to hear and play out the motivic line over one or two other voices is much easier than playing everything at once! The same practice technique will be helpful with the bass-clef line as well, playing those with both hands. A good next step would be to play the section several times very slowly as it is written, while carefully listening for each individual motivic line in turn. For instance, when playing mm. 20-22 as written, one might bring out Figure 3.5c the first time through, then bring out Figure 3.5d the second time, and Figure 3.5e the third time, etc. This 
practice brings the benefit of playing the same passage a number of times, because so many motivic elements are intertwined in this material.

In m. 37, Rzewski sets "Gonna lay down my sword and shield" (Figure 3.1) in an unprecedented style that is very different from sections A and B. This third section, in the key of E-flat, is marked poco più mosso, which translates to a little more motion. Bell describes this as a short episode that relieves the textural density; its obbligato accompaniment, with a dominant Bflat pedal point, resembles those found in nineteenth-century piano writings. ${ }^{11}$ This E-flat section in 9/8 meter, which is marked Con pedale and m.s. sempre pp, requires the generous use of pedal and a soft dynamic in the left hand. The cross rhythm between the right hand and the left hand is not difficult to play. However, the top voice on $\mathrm{G}$ of the right hand should be brought out enough to last its full value. The pianist also needs to pay attention to the two dotted-sixteenth notes, Fsharp and A-flat, in order to match the sound of what is left from the initial $G$ in the beginning of m. 37 (Figure 3.6).

Figure $3.6 \mathrm{~mm} .37-39$

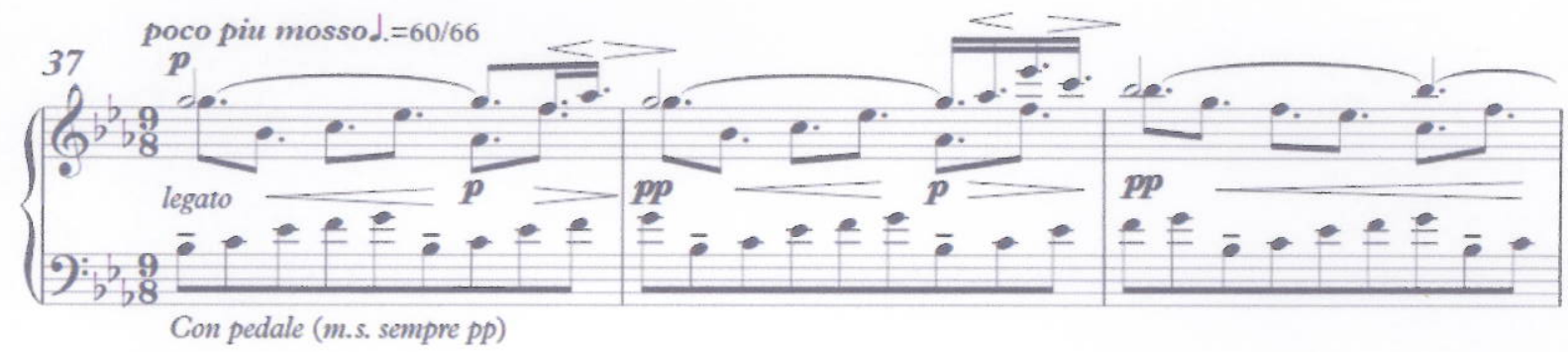

(C) Rzewski "Down by the Riverside" from NORTH AMERICAN BALLADS. Copyright 1979 by Zen-On Music Co. Ltd. All Rights Reserved. Used by permission of European American Music Distributos Company, sole U.S. and Canadian agent for Zen-On Music Company Limited.

${ }^{11}$ Larry Bell \& Andrea Olmstead, "Musica Reservata in Frederic Rzewski's 'North American Ballads"' The Musical Quarterly Vol. 72, No. 4, 1986, p. 454. 
Rzewski's use of extreme dynamic contrasts adds to the difficulty of the piece. He explains the reason for this as his having to perform many pieces by Stockhausen and Boulez, who are known for exploiting extreme registers and dynamics. ${ }^{12}$ Figure 3.7 reveals the first of three passages, all of which are marked as fortississimo, the loudest dynamic in this piece, beginning in $\mathrm{m} .57$ with a succession of five-note chords. Extreme contrast begins in $\mathrm{m} .55$, where the dynamic grows from piano to forte during two beats, with the right and left hands spanning five octaves on the F-sharps at the end of the measure. This intensity is maintained throughout mm.56-58, with the left-hand octaves reaching from E down to the lowest B-flat and followed by G-major chords juxtaposed with F-sharp major chords, which are placed six octaves above the bass B-flat. Despite extreme dynamic range, register shifts, and tone clusters, the folk elements are never lost. I find it almost hypnotic when the distinctive rhythm can still easily be heard through the tone clusters in mm. 57-58. The pianist must not anticipate the pianissimo beginning in $\mathrm{m} .59$, which recalls section C. Please take the breath mark, between $\mathrm{m} .58$ and 59 , into consideration and pause briefly so that the fortissimo sounds in $\mathrm{m}$. 58 can clear. Rzewski wants this particular passage to be extreme and vulgar as opposed to "smooth" in the conventional sense of classical music. ${ }^{13}$ (Figure 3.7)

\footnotetext{
${ }^{12}$ Sujin Kim. Rzewski interview by author, p. 97.

${ }^{13}$ Ibid., p. 99.
} 
Figure $3.7 \mathrm{~mm} .55-58$
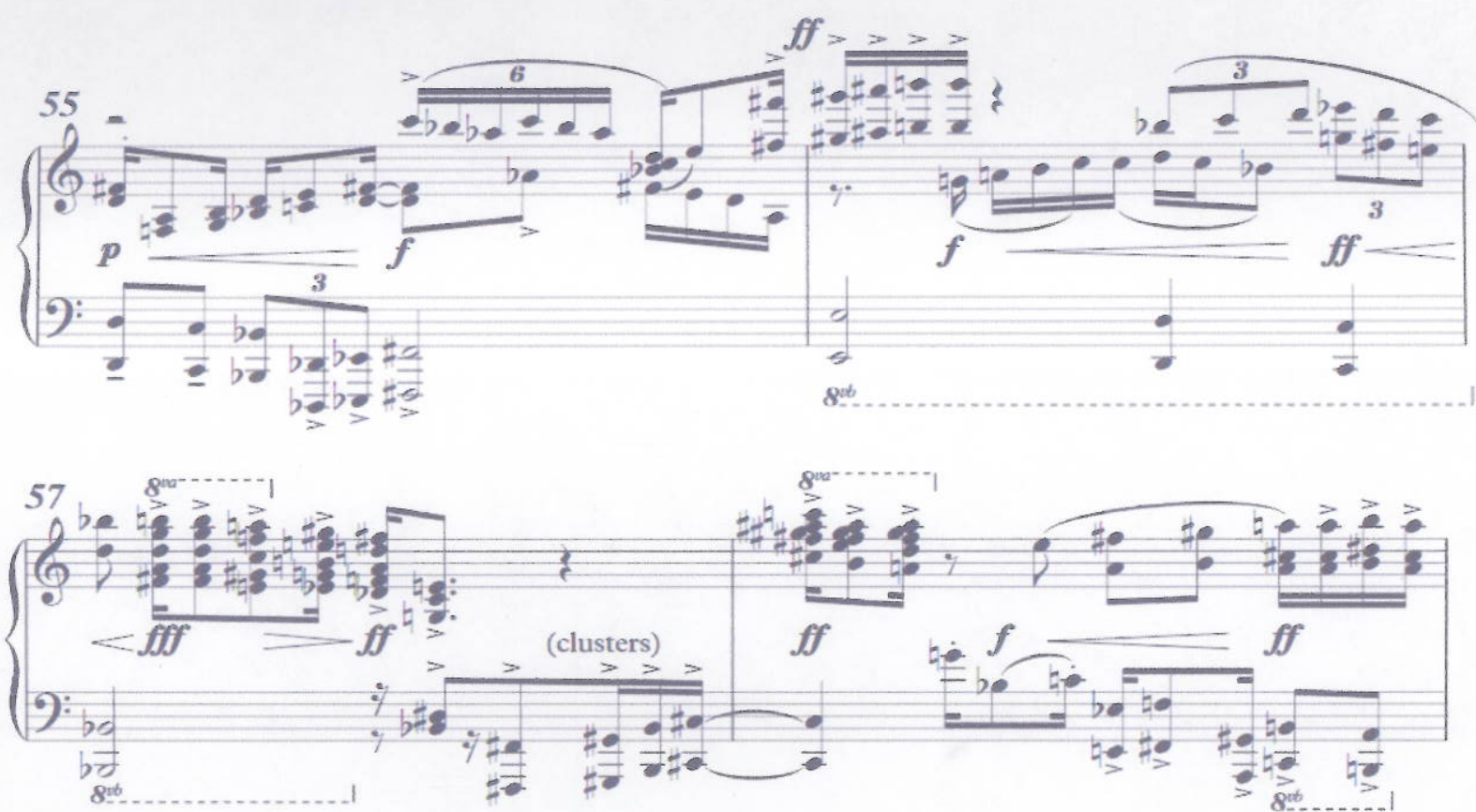

(C) Rzewski "Down by the Riverside" from NORTH AMERICAN BALLADS. Copyright 1979 by Zen-On Music Co. Ltd. All Rights Reserved. Used by permission of European American Music Distributos Company, sole U.S. and Canadian agent for Zen-On Music Company Limited.

After the contrapuntal sections, optional improvisation is inserted in $\mathrm{m} .62$ on an A-flat major chord over a $\mathrm{D}$ pedal point. If an improvisation is played, it should begin and end on the chord stated above. With or without the improvisation, we find a smooth transition to the fourth section that brings back the $\mathrm{D}$-major tonality in $\mathrm{m}$. 67. Beginning the $\mathrm{D}$ section, a 16 -measure passage is carefully constructed in a blues style by the composer. The left hand plays a walking bass which exhibits a four-measure phrase that is repeated twice. The pianist is encouraged to play the left hand alone without the doubled octave, to memorize this passage quickly. Two-hand practice for the upper register enhances the clarity of the notes, which are written in a jazz style. Another way of practicing this particular passage is to play only the bass and the soprano, in order to hear the harmonic progression. Rzewski swings the sixteenth notes of the right hand in 
his recording. Marc-André Hamelin does not swing, but takes more of a classical approach to the piece, with the optional improvisation omitted and observing the tempo indicated in the score, which is faster than Rzewski's own performance. ${ }^{14}$ This section D is to be played twice, gradually growing from pianississimo to fortississimo, and adding the original tune in the tenor voice. The repetition creates a powerful culminating effect.

Section $\mathrm{E}$, beginning in $\mathrm{m} .83$, is marked as the coda with another optional improvisation section in the cadenza. The parallel tenths in the left hand recall right-hand notes from section $\mathrm{C}$ and settle on F sharp in the bass, which is the enharmonic spelling of G flat, the first pitch of the $4^{\text {th }}$ ballad.

\section{Improvisation}

As discussed in Chapter One, Rzewski believes that improvisation is a very important part of classical music and he strongly encourages students to simply "put their fingers on the keys and wriggle them," lack of experience notwithstanding. ${ }^{15}$ Most classical musicians do not get a chance to develop improvisational skills. Having not developed strong improvisational skills myself, I understand this concern and realize that in some cases decisions need to be made in advance.

The first of the two improvisations in this piece are placed in the middle, before section $\mathrm{D}$, where the Baroque passcaglia is combined with jazz styles. The only instruction given by the composer is that the length of such parts be the same as the preceding written music. This

\footnotetext{
${ }^{14}$ CDA 67077 The People United Will Never Be Defeated! Down by the Riverside and Winnsboro Cotton Mill Blues from North American Ballads. Hyperion: London: 1999.

${ }^{15}$ Sujin Kim. Rzewski interview by author, p. 81 .
} 
instruction leads to the decision that the improvisation should share the same vocabulary with the preceding written part rather than playing something in a completely different style.

One who does not have any improvisational skills can start with the original tune Rzewski uses in the very beginning. Experiment with the right-hand melody using rhythmic alteration while maintaining the left-hand ostinato. The rhythmic vocabulary for this particular piece exhibits very strong rhythmic figures. Robert Christian Paul lists possible ideas for improvisation, including melodic vocabulary, rhythmic vocabulary, harmonic vocabulary and counterpoint, and treatment of texture and timbre. ${ }^{16}$ However, Paul finds a gospel-style improvisation to be most successful for this particular piece; that is, to incorporate rhythmic structures and textures found in gospel music. Perhaps, the use of polytonality is another consideration for improvisation in this section.

\section{$\underline{\text { Conclusion }}$}

This seven-page piece represents Rzewski's eclecticism at its best. His skillful craftsmanship successfully melds gospel style, new romanticism, baroque counterpoint, and a combination of passacaglia and blues. Despite the challenges for the pianist in the complex contrapuntal section, the piece rewards those who master it, and audiences enjoy the familiarity of one of the best-known spiritual tunes. This is a great piece to use to introduce music conservatory students to contemporary music and to move their attention to improvisation early enough that they can develop this skill.

\footnotetext{
${ }^{16}$ Robert Christian Paul. "Improvisation in Twentieth-Century Solo Piano Repertoire, as Represented in Alvin Curran's First Piano Piece (1967) and Pieces Selected from Squares (1978) and Four North American Ballads (1978-1979), by Frederic Rzewski.
} 


\section{Chapter 4}

\section{"Winnsboro Cotton Mill Blues"}

Rzewski's fourth ballad, "Winnsboro Cotton Mill Blues," is a most imaginative and effective-sounding piece. The vivid depiction of powerful machinery juxtaposed with an intimate section of written-out blues creates a picturesque scene of industrial life in 1930s America. This is not an easy piece to learn, in part because the playing is simultaneously conventional (no paper clips or other "preparations" and no plucking of strings inside the piano) and unconventional (much of the piece uses the keyboard for clusters, rather than more traditional technique). Playing this piece requires a great deal of physical strength, good technique in order to effectively execute tone clusters and complex rhythms, and a thorough understanding of dissonant counterpoint and jazz. Yet those who take the time to learn it reap rich rewards, because the dramatic effect is far greater than the sum of the difficulties.

The first four pages, which can be overwhelming for some players, are completely covered with sixteenth-note clusters which reflect a motoric minimalism. Alternating semitones, the lowest F and G-flat on the piano, begin very softly and gradually expand to loud octave clusters, which involve the use of palms and forearms. Although Rzewski marks "expressionless, machinelike" at the beginning, these clusters produce a deep and resonant sound which creates a feeling of "heightened anticipation."1

For efficiency and clarity, the pianist needs to be aware of the systematic nature of the piece, which prevails through gradual changes. "Additive processes" are an important element,

\footnotetext{
${ }^{1}$ Seth Beckman, "The Traditional and the Avant-Garde in Late Twentieth-Century Music: A Study of Three Piano Compositions by Frederic Rzewski” (DMA diss., Ball State University, 1996), p. 130.
} 
stemming from minimalist tradition; this has appeared in other Rzewski compositions such as Les Moutons de Panurge (1968) along with Coming Together and Attica, both written in $1972 .^{2}$

As a way to unlock the structure of this section, we can assign numbers to the types of clusters and then see how Rzewski arranges them. In that context, the pianissimo semitone clusters at the beginning are labeled number 1 . The subsequent five-note clusters in piano get the number 2 , and it is interesting to note that a fragment of the original folk tune is inserted during the last beat, as shown in Figure 4-1 below. We can assign number 3 to the octave clusters in mezzo-piano, in which the two accented notes on the last beat depict the changing gears of the mill. ${ }^{3}$ These labeling numbers reflect both the increasing width of each cluster as more notes are added, and also a related increase in volume. Within this labeling system, the first eight measures unfold in the following order: 1-2-1-2-1-3-2-1-(3-3). The last two measures of octave clusters seem restless and intense as they grow louder into forte. It is almost unnecessary for the performer to "do the dynamics," because they happen spontaneously as the number of simultaneous notes changes. Each group of clusters lasts for twelve quarter-note beats per measure and it is advisable to count each beat to avoid pulsation within a measure as well as getting lost in motoric repetitions. For the pianist, there is little here that requires "practice," in the traditional sense of that word; however one must know where the little changes occur.

\footnotetext{
${ }^{2}$ Kyle Gann, American Music in the Twentieth Century (New York: Schirmer Books, 1997), p. 235.

${ }^{3}$ Sujin Kim, interview with the composer, p.102.
} 
Figure $4.1 \mathrm{~mm} .1-2$
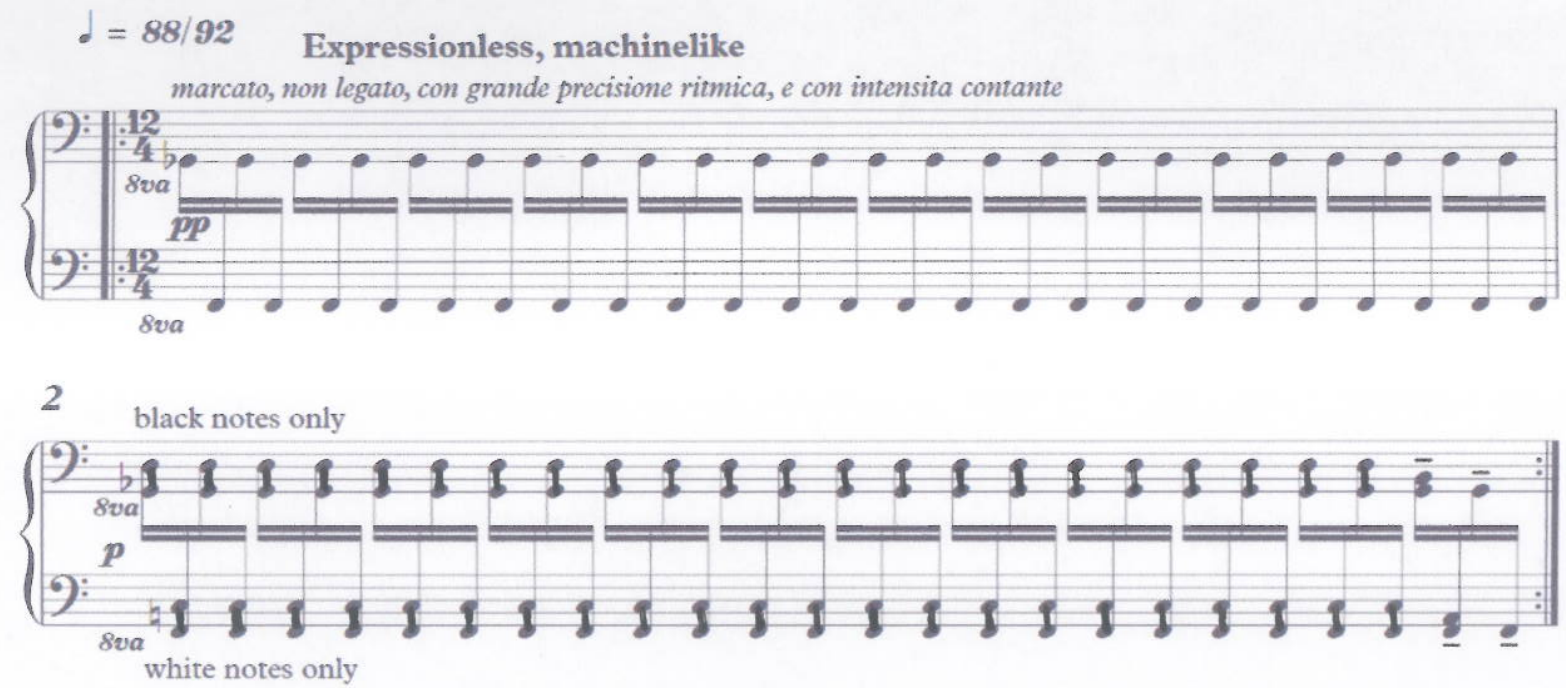

(C) Rzewski "Winnsboro Cotton Mill Blues" from NORTH AMERICAN BALLADS. Copyright 1979 by Zen-On Music Co. Ltd. All Rights Reserved. Used by permission of European American Music Distributos Company, sole U.S. and Canadian agent for Zen-On Music Company Limited.

In the beginning, great control is required to maintain pianissimo and non legato as instructed by the composer. For a smooth transition from the semitone clusters to the five-note clusters, consider using the fifth finger of the left hand on $\mathrm{F}$ and the second finger of the right hand on the G-flat. The tenuto in m. 2 marks an elusive fragment of the folk melody on the last beat which may not be easily recognized by those who are not familiar with it. An alternative is to bring out two D-flats in the right hand on the penultimate beat within the measure. This offers the audience something they can recall when the folk tune is reintroduced in $\mathrm{m} .51$. The decision whether or not to voice these two D-flat notes is left to the performer's discretion.

The mysterious cluster introduced in $\mathrm{m} .9$, which involves playing with the right elbow, marks a new phase in the context of the haunting motoric figuration. Supported by our hypothetical number-3 octave clusters rambling on underneath, the G-flat cluster in pianississimo is intended to sound eerie at first. In the score, Rzewski instructs the pianist that these notes are 
to be "a subtle coloration" rather than "precisely executed"; however, there is also evidence that they should be brought out at least a bit, because the passage is supposed to get louder gradually and because they outline the blues scale. Rzewski here uses systematic accumulation again. In each measure an extra note-cluster is added on top of what is introduced in the preceding measure. This process is executed over sixteen measures, culminating in a G-flat pentatonic scale with an added raised sixth of blues; that outlines G-flat, A-flat, B-flat, D-flat, E-flat, and Enatural. (Figuration 4.2) The blue note, E-natural, is poignant to the ears and its repetition in forte creates a dramatic effect.

Figure $4.2 \mathrm{~mm} .19-22$
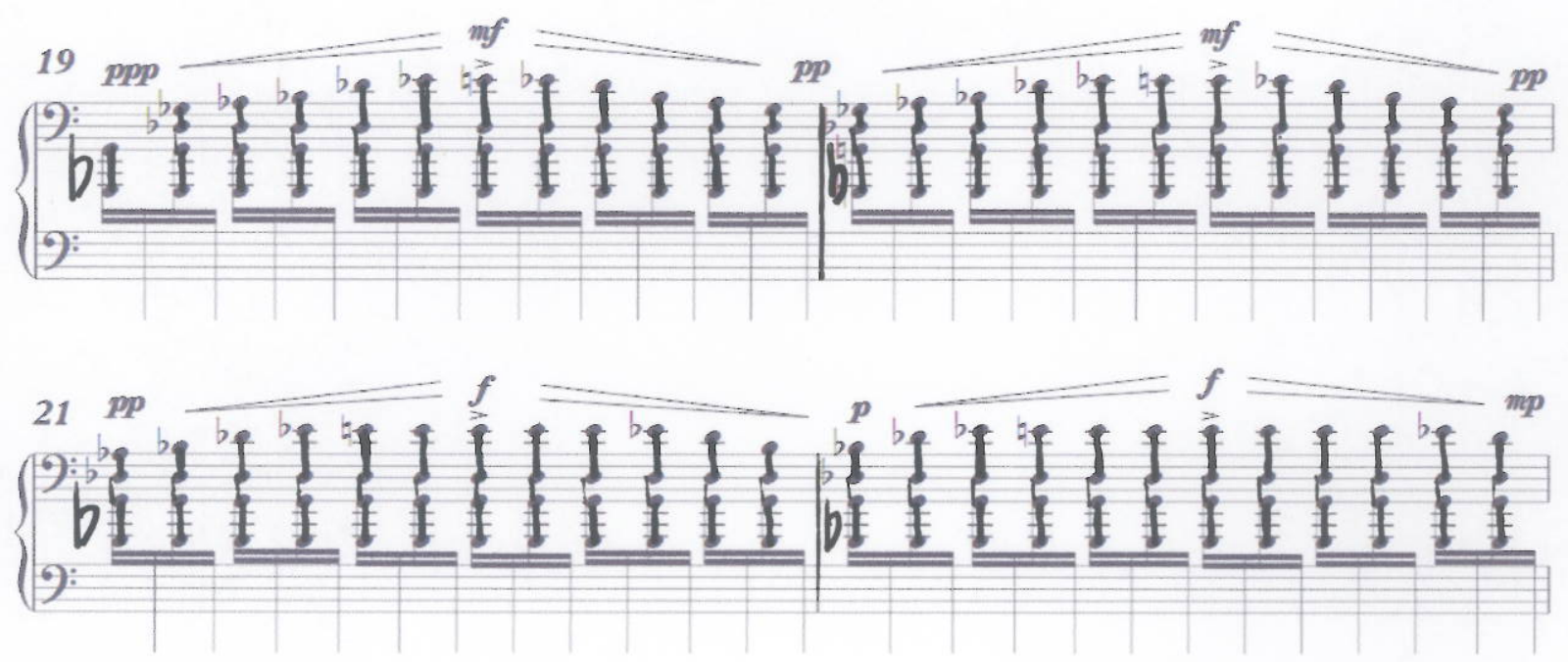

(C) Rzewski "Winnsboro Cotton Mill Blues" from NORTH AMERICAN BALLADS. Copyright 1979 by Zen-On Music Co. Ltd. All Rights Reserved. Used by permission of European American Music Distributos Company, sole U.S. and Canadian agent for Zen-On Music Company Limited. 
The interpretation of this passage can vary significantly, depending on the pianist's artistic taste. Marc-André Hamelin's performance ${ }^{4}$ differs from Emanuele Arciuli's ${ }^{5}$ : Hamelin's absolutely non-voiced clusters reflect the striking reality of the industrial era, whereas Arciuli's preciselyvoiced clusters almost seem a bit out of place. Rzewski chooses the middle ground, as he brings out the elbow clusters moderately. ${ }^{6}$ Beginning in measure 9 through measure 25 , I suggest practicing the top voice, which is supposed to be played with the elbows, with the right hand alone. The pianist should practice the bass clusters, which should also be played with the elbows, with the left hand. Playing the clusters on every beat will aid the pianist in hearing how the blues scale unfolds in each measure. This will give the pianist a clearer idea of the rhythm and melody. As the first section of the machinery winds down in $\mathrm{m} .32$, the rocking seconds between the right and left hands can be replaced by just the right hand. Fingers 2 and 3 play the D-flat and D-natural while the thumb plays the two lower notes, B and C (Figure 4.3). This enables the right hand to continue the motoric figuration uninterrupted in the next measure. The suggested fingering numbers for the right hand are 2 on D-flat and 1 on C, whereas the left hand plays Dnatural and B; left hand fingerings are left to the pianist's discretion. The semitones diminuendo gradually in $\mathrm{m} .34$ as if anticipating what is to happen next.

\footnotetext{
${ }^{4}$ Frederic Rzewski, "Winnsboro Cotton Mill Blues," Marc-André Hamelin, Hyperion Digital CDD, 1998.

${ }^{5}$ Emanuele Arciuli, live performance at 2008 Miami International Piano Festival.

${ }^{6}$ Rzewski plays Rzewski. Nonesuch.
} 
Figure $4.3 \mathrm{~mm} .32-33$
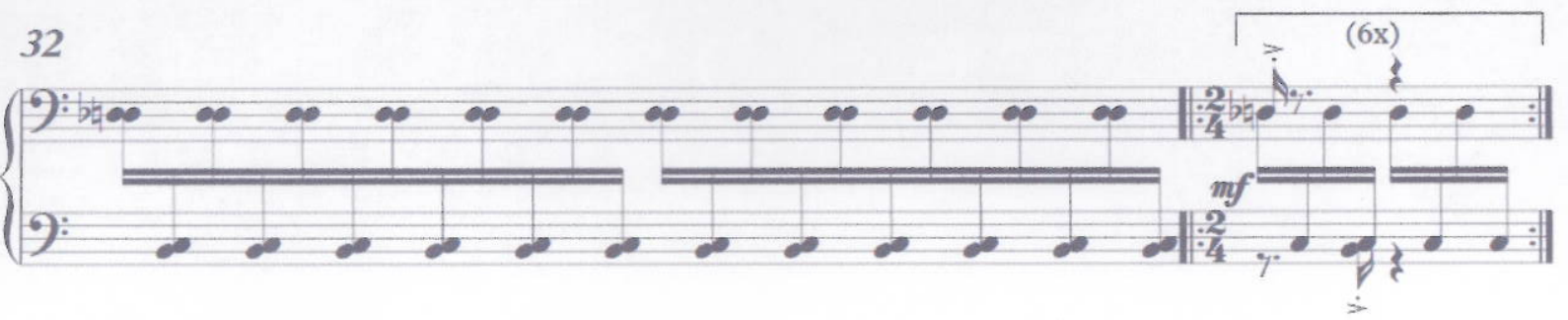

(C) Rzewski "Winnsboro Cotton Mill Blues" from NORTH AMERICAN BALLADS. Copyright 1979 by Zen-On Music Co. Ltd. All Rights Reserved. Used by permission of European American Music Distributos Company, sole U.S. and Canadian agent for Zen-On Music Company Limited.

A new section is created as the note $\mathrm{F}$ is added to the continuously rocking semitone D-

flat and C. As a result, the general atmosphere changes instantly. It sounds a little more stylized and lightened as the bass note $\mathrm{F}$ dings at the bottom and the accent on the fourth sixteenth-note creates syncopation. ${ }^{7}$ In his recording, Rzewski brings out this bass note $\mathrm{F}$ with tenuto. The pianist needs to be aware of the note which changes the pattern in every measure. Suggested fingerings and markings for an accurate performance of this section are indicated in figure 4.4.

Figure 4.4 mm. 35-38

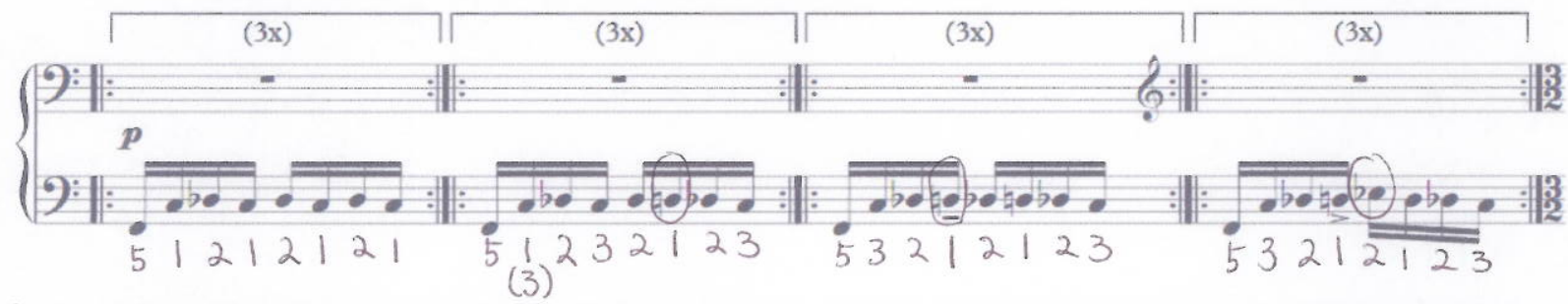

(C) Rzewski "Winnsboro Cotton Mill Blues" from NORTH AMERICAN BALLADS. Copyright 1979 by Zen-On Music Co. Ltd. All Rights Reserved. Used by permission of European American Music Distributos Company, sole U.S. and Canadian agent for Zen-On Music Company Limited.

This left-hand ostinato remains absolutely unchanged until m. 59, juxtaposed with piercing blues chords laid out over twelve bars with the bass note changing. Finally, in m. 51, the long-awaited folk tune appears in a bluesy rhythm in the right hand; syncopation is created as a half-note

\footnotetext{
${ }^{7}$ Sujin Kim, interview with Rzewski, p. 105.
} 
triplet is followed by a whole note, then a quarter-note, and then a dotted-half note. In order to execute this rhythm correctly even at a slower tempo, I suggest that a pianist calculate precisely how many of the sixteenth-notes are to fit into the right hand melody. The original folk tune is indicated in Figure 4.5. Figures 4.6a and 4.6b indicate Rzewski's setting.

Figure 4.5 The original tune "Old man Sargent"8
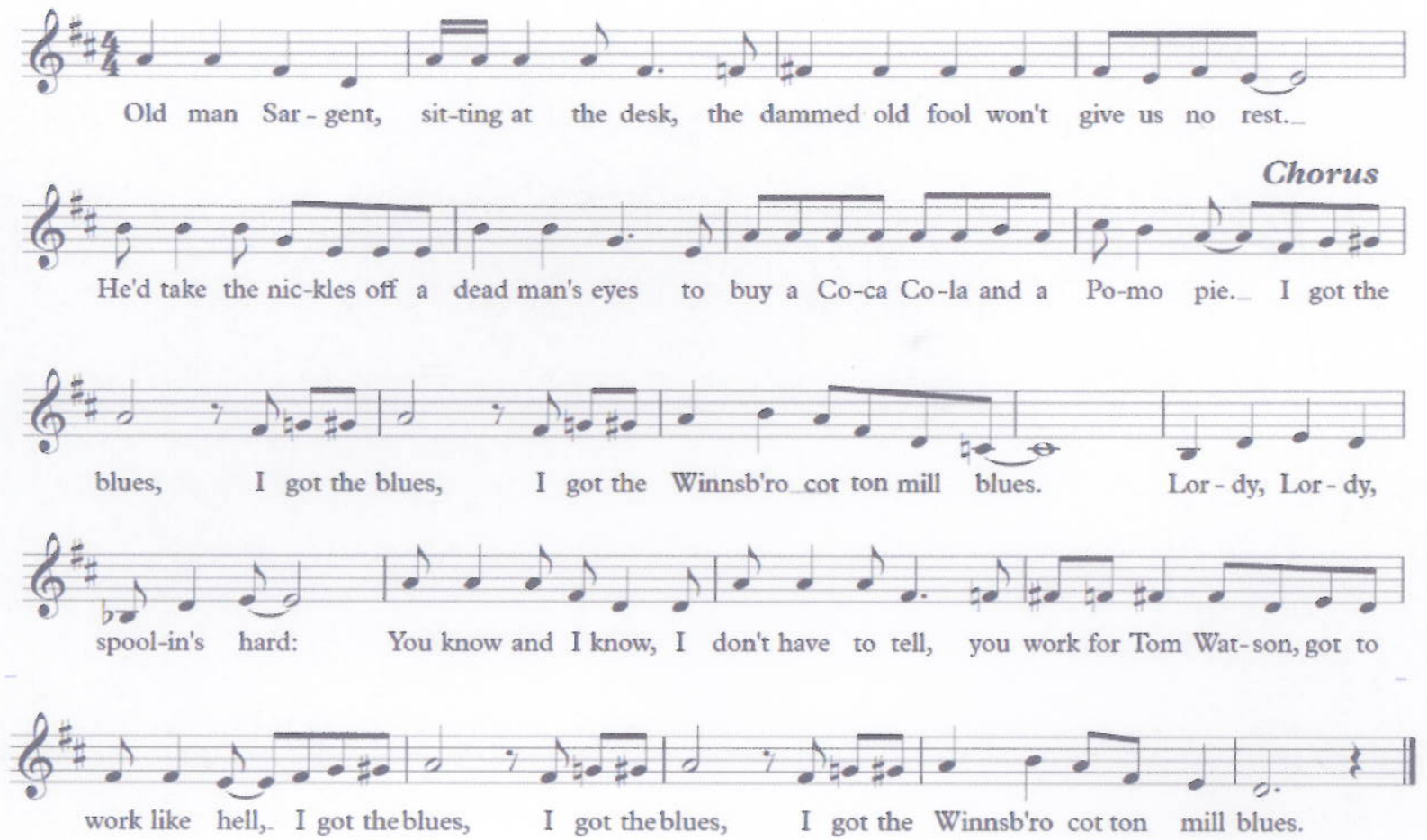

${ }^{8}$ Vanessa Cornett-Murtada, "Quotation, Revolution, and American Culture: The Use of Folk Tunes and the Influence of Charles Ives in Frederic Rzewski's North American Ballads for Solo Piano." (DMA diss., The University of North Carolina at Greensboro, 2004), p. 88. 
Figure 4.6a m. 51

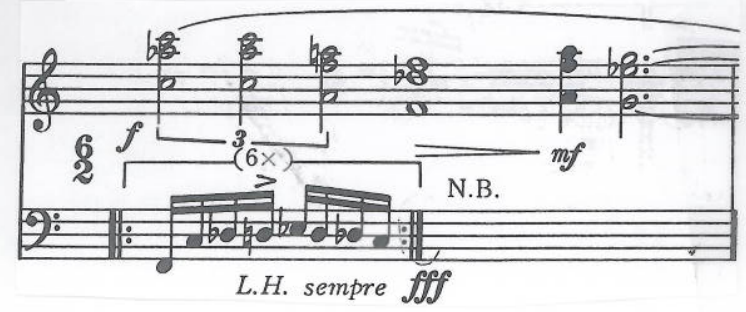

(c) Rzewski "Winnsboro Cotton Mill Blues" from NORTH AMERICAN BALLADS. Copyright 1979 by Zen-On Music Co. Ltd. All Rights Reserved. Used by permission of European American Music Distributos Company, sole U.S. and Canadian agent for Zen-On Music Company Limited.

Figure $4.6 \mathrm{~b}$ written-out sixteenth notes in accompaniment.

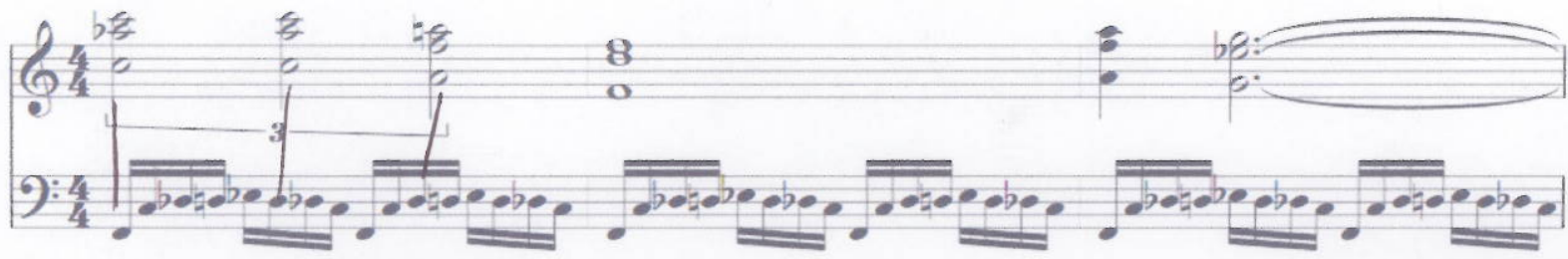

(C) Rzewski "Winnsboro Cotton Mill Blues" from NORTH AMERICAN BALLADS. Copyright 1979 by Zen-On Music Co. Ltd. All Rights Reserved. Used by permission of European American Music Distributos Company, sole U.S. and Canadian agent for Zen-On Music Company Limited.

This passage can be challenging for classical pianists due to the imbalance of the melody and the accompaniment. Most pianists are trained fervently to bring out melody over accompaniment.

One must defy the norm and keep the left hand ostinato accompaniment extreme in fortississimo incessantly while making one's best effort to let the right-hand melody disappear in mm. 56-58.

In $\mathrm{m} .59$, the right hand sneaks in a chromatic scale, beginning with a perfect fifth leap in pianississimo, parallel to the left-hand figuration which had been played in preceding measures. This measure repeats six times, as the right-hand scale gradually gets louder from pianississimo to forte, balancing with the left hand's forte (down from fortississimo). These scales are juxtaposed a minor ninth apart vertically and they produce intense dissonance when played simultaneously; yet this does not offend the listener because the repetition has been lingering in 
the ear over the preceding 20 measures. In m. 60, fragments of the folk tune, "Old Man Sargent," appear in the keys of B-flat, A, and B, amid incessant motoric figuration.

Practice suggestions for this passage might include working on each fragment out of context, followed by practicing the left and right hands separately while making sure to bring out the folk melody. The technical demands are intensified in mm. 68-80, where the right-hand interval of a major ninth consistently clashes with the left hand's minor ninth. This demands stretching and extending of the hands; therefore, the pianist is encouraged to practice without the middle notes. Despite the complexities produced in mm. $69-74$ by changing rhythms and wide spans between chords, this section serves as a driving force toward ending the clamor of the machinery. In mm. 75-85, we see the marking martellato ("hammered"), with each hand reaching the opposite end of the piano. The intensity of this hammering is left to the pianist's interpretation; however, one must take it into consideration that Rzewski despises the idea of "pounding" on the piano. ${ }^{9}$ This is evident in his Nonesuch recording ${ }^{10}$ in comparison to other pianists such as Roger Wright ${ }^{11}$ and Oscar Jezior. ${ }^{12}$ The "hammered" clusters require flattened fingers and an up-and-down wrist motion in order to execute mm. 79-80 successfully; this is illustrated in Figure 4.7.

\footnotetext{
${ }^{9}$ Sujin Kim, interview with Rzewski. He watched David Tudor closely and observed that Tudor always had fingers in contact with keyboard and no excessive gesture. p. 112.

${ }^{10}$ Rzewski plays Rzewski. Nonesuch.

${ }^{11}$ Roger Wright, 2009 Van Cliburn Competition live performance. http://www.youtube.com/watch?v=jhrHK0ySh68.

${ }^{12}$ Oscar Jezior, 2012 Helsinki International Maj Lind Piano Competition live performance. http://www.youtube.com/watch?v=oR1rXJ6JQoM.
} 
Figure $4.7 \mathrm{~mm} .74-80$
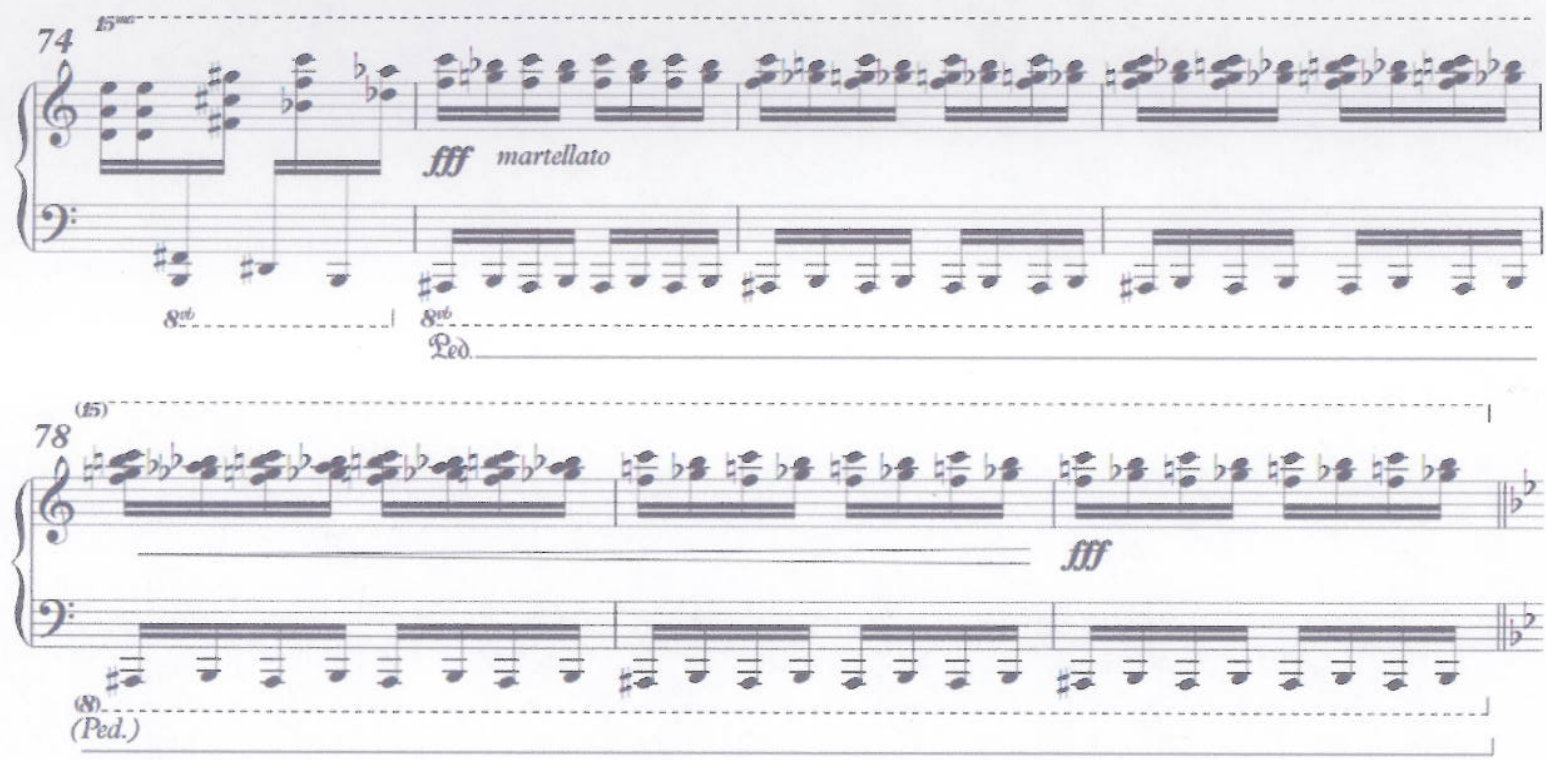

(C) Rzewski "Winnsboro Cotton Mill Blues" from NORTH AMERICAN BALLADS. Copyright 1979 by Zen-On Music Co. Ltd. All Rights Reserved. Used by permission of European American Music Distributos Company, sole U.S. and Canadian agent for Zen-On Music Company Limited.

The beginning of the work represents the din of the machinery from the cotton mill; this section lasts for 85 measures. A written-out blues section that begins in measure 86 marks the next section; here there is no trace of any motoric figuration or alternating clusters. This is an exquisitely written-out blues by a composer with consummate skill in playing jazz. It is Rzewski's intent that this section should sound as if it is being played by a jazz pianist. His entire blues setting is taken from the chorus of the original tune and is written in 12/8. As might be expected from a blues, this section contains many minor-third, minor-sixth, and minor-seventh scale degrees, frequent grace notes, and rhythmic syncopation.

At first, the pianist needs to feel the eighth notes in groups of three--that is, four beats per measure (12/8 time signature). However, after becoming more comfortable with this section, the pianist should feel two large beats per measure. In order to do justice to the blues style, one cannot play each eighth note and sixteenth note strictly metrically —-they need to swing! For 
instance, in $\mathrm{m} .87$, the first group of sixteenth notes on beat one needs to be played rather quickly, and the inner voice which begins with the F-natural at the end of beat 1 and continuing with the D-flat, then D-natural, and ending with the B-flat in the tenor on beat three should be brought out with a bit more emphasis on the bluesy D-flat in the alto voice. With an accented D-flat in the soprano, the last sixteenth-note in that measure should be rushed to reach D-flat and C, followed by the B-flat tonic on beat one and two in $\mathrm{mm}$. 88; this is illustrated in Figure 4.8. The classical pianist is encouraged to listen to some blues recordings in order to learn the appropriate style.

Figure $4.8 \mathrm{~mm} .86-88$

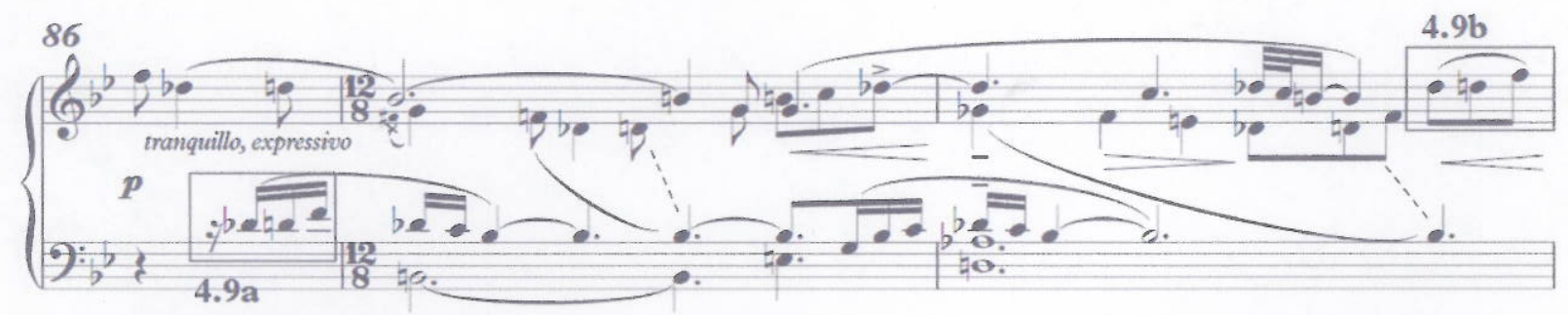

(C) Rzewski "Winnsboro Cotton Mill Blues" from NORTH AMERICAN BALLADS. Copyright 1979 by Zen-On Music Co. Ltd. All Rights Reserved. Used by permission of European American Music Distributos Company, sole U.S. and Canadian agent for Zen-On Music Company Limited.

As briefly mentioned above, Rzewski transforms melodic fragments from the chorus of the original song into a very bluesy style. Melodic fragments which are reminiscent of the song "I got the blues" and comprised of the notes D, E-flat, E-natural, and F (Figure 4.9) are prominent in this section. Examples include: M. 86, beat two, in the tenor (Figure 4.9a); m. 88, beat four, in the soprano (Figure 4.9b); m. 90, beat one, in the soprano (Figure 4.9c); m. 94, beat one in the soprano (Figure 4.9d); and m. 95, beat one, in the bass (Figure 4.9e). 
Figure 4.9 "I got the blues," from the original song in B-flat major

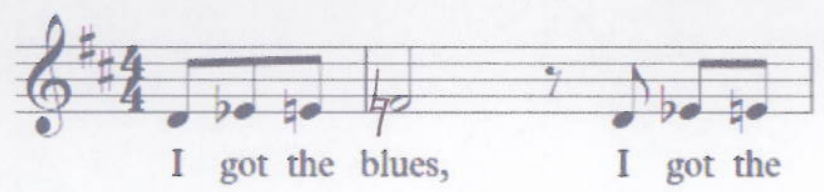

(C) Rzewski "Winnsboro Cotton Mill Blues" from NORTH AMERICAN BALLADS. Copyright 1979 by Zen-On Music Co. Ltd. All Rights Reserved. Used by permission of European American Music Distributos Company, sole U.S. and Canadian agent for Zen-On Music Company Limited.

Figure 4.9 fragments $\mathrm{c}, \mathrm{d}$, and e; fragments a and $\mathrm{b}$ appear in Figure 4.8 above.
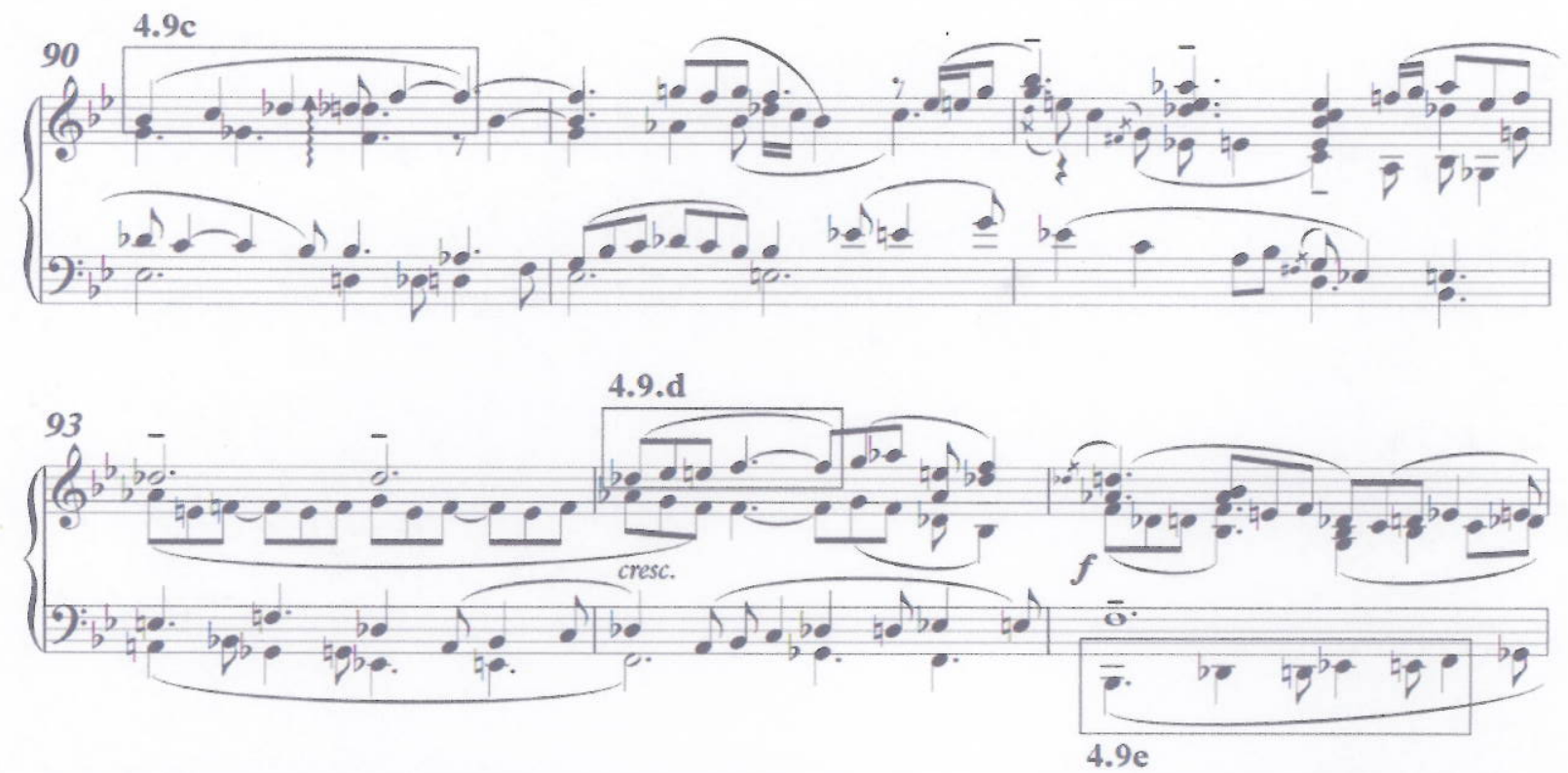

(C) Rzewski "Winnsboro Cotton Mill Blues" from NORTH AMERICAN BALLADS. Copyright 1979 by Zen-On Music Co. Ltd. All Rights Reserved. Used by permission of European American Music Distributos Company, sole U.S. and Canadian agent for Zen-On Music Company Limited.

Another prominent use of the original chorus is in mm. 99-100, "Lordy Lordy, Spoolin's hard" in E-flat major followed by an E-flat minor seventh, reminiscent of Gershwin's piano writing. This is illustrated in Figure 4.10. 
Figure $4.10 \mathrm{~mm} .99-100$

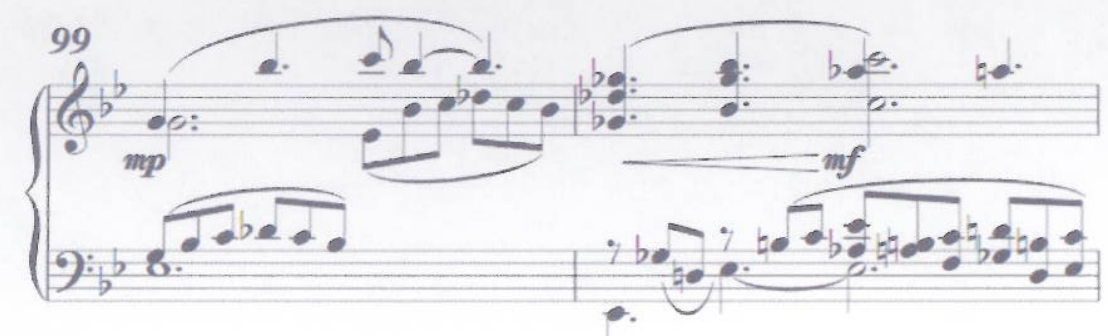

(C) Rzewski "Winnsboro Cotton Mill Blues" from NORTH AMERICAN BALLADS. Copyright 1979 by Zen-On Music Co. Ltd. All Rights Reserved. Used by permission of European American Music Distributos Company, sole U.S. and Canadian agent for Zen-On Music Company Limited.

In mm. 104-108, "I got the blues" in its original form is presented within this fantasy-like passage. The right-hand melody in octaves with tenuto markings is supported by the dominant scale degree, F; it then moves to the tonic, B-flat, at the word "blues" from the "I got the blues" motive. This is immediately echoed in the right hand in $\mathrm{m} .105$. In this climactic passage, which is illustrated in Figure 4.10, one can imagine a blues singer wailing, "I got the Blues," supported by a virtuoso pianist playing chromatic scales underneath. My suggestions for fingering appear in Figure 4.10. The pianist is encouraged to practice each hand separately, in order to find their own fingerings, and then to repeat the passage in smaller sections with both hands. The threenote clusters in $\mathrm{m} .107$ consist of a third with an extra semitone added to the lower note. These chords create a grace-note embellished sound. Furthermore, the rhythmic syncopation adds more jazz flavor to this section. The blues section fades out as the right hand melody plays the end of the song with the semitone drone in the bass, which provides a smooth transition into the next section. 
Figure $4.11 \mathrm{~mm} .104-107$
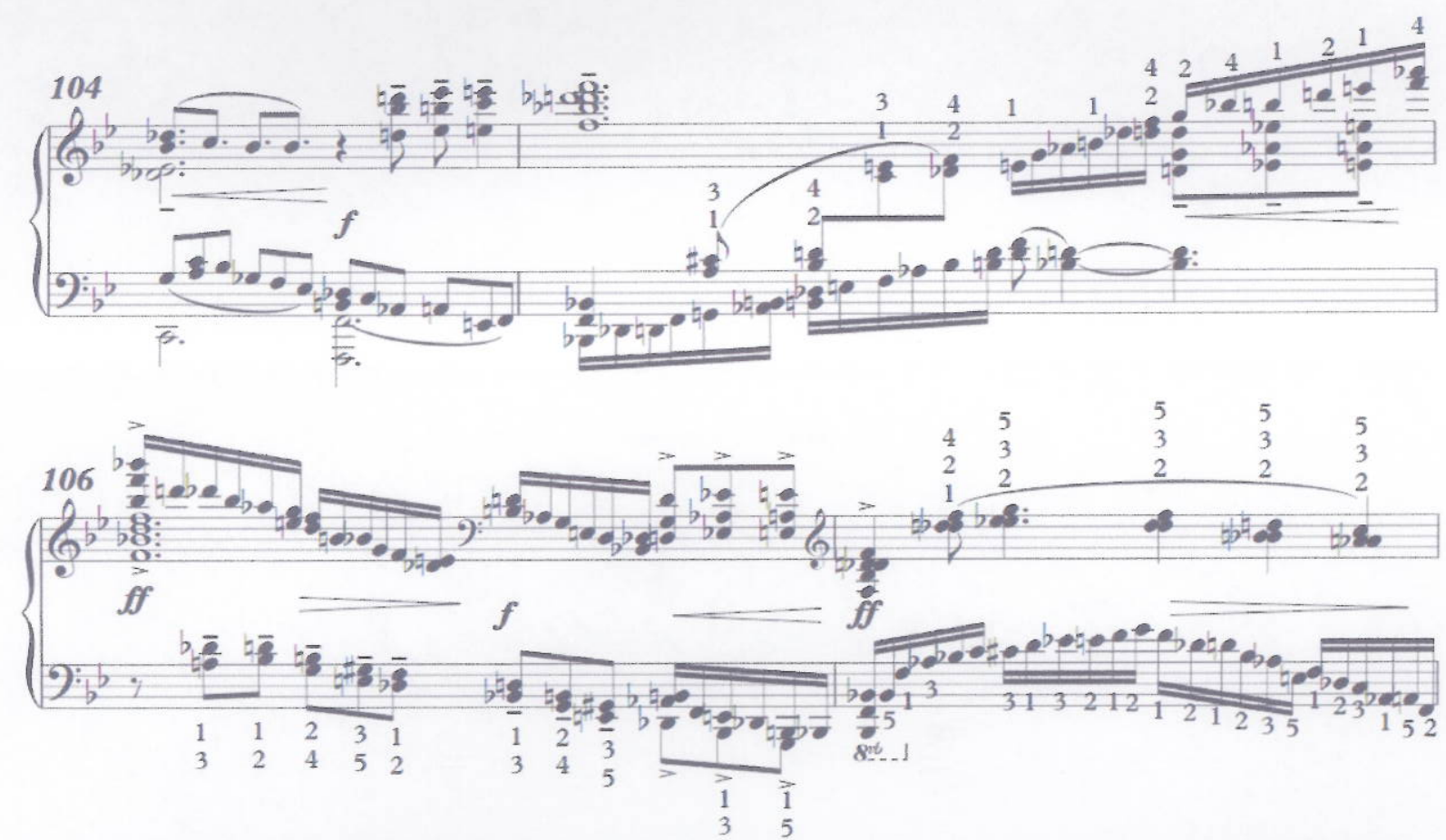

(C) Rzewski "Winnsboro Cotton Mill Blues" from NORTH AMERICAN BALLADS. Copyright 1979 by Zen-On Music Co. Ltd. All Rights Reserved. Used by permission of European American Music Distributos Company, sole U.S. and Canadian agent for Zen-On Music Company Limited.

The next section marks the come prima, bringing back the machinery in $4 / 4$, pianississimo. An entire verse of "Old Man Sargent" is quoted in G-flat major; then begins a development which is technically and musically most demanding. Rzewski intentionally composes very difficult sections such as this development in all of his piano compositions to keep mediocre pianists from playing his works. ${ }^{13}$ This section uses extensive melodic fragments in stretto. The pianist is strongly encouraged to analyze this section, tracing and marking each melodic fragment on the score. ${ }^{14}$ Using both hands for playing the treble clef and the bass clef separately enables the pianist to hear the melodic fragments and to understand the complex rhythm more clearly.

\footnotetext{
${ }^{13}$ Kim Hayashi, p. 128.

${ }^{14}$ Refer to Sujin Kim, p.64-65 in Appendix A.
} 
I recommend the following practice method: play one measure of the treble clef using both hands and then repeat the same measure "as written," with just the right hand. The next step is to play the left hand alone--or to use both hands to play the bass clef if it seems too complex. One needs to be aware of the wide leaps and to practice them in both of these ways until one feels comfortable and easy. I suggest trying a measure or two with both hands, to explore memorizing each fragment as early as possible. I find that the eighth-note at 60 beats per minute gives an appropriate initial tempo for practice. The pianist should continue to practice while moving the tempo up in small increments.

Rzewski indicates a pedal mark on beat four in $\mathrm{m}$. 132, where the right hand plays "I got the blues" in octaves with accents, following another martellato section gradually getting softer from fortissimo to piano. This transitions to the original song, this time in its entirety, set in Fmajor with a boogie-woogie accompaniment. It is fascinating that the original tune is introduced twice, in the key of G-flat and F, respectively; these are the two opening notes of the entire piece. This passage ends abruptly with obnoxiously loud forearm clusters in $\mathrm{m}$. 147 . One should note these clusters are intended to convey upward motion, but not to produce specific chords. The pedal marking beginning in $\mathrm{m} .147$ with the forearm clusters is intended to last until the end of the piece. The rolled clusters in the last eight measures create a glassy sound, played in the highest notes of the piano. There is a hint of "Old Man Sargent" in $\mathrm{m} .152$ when the right-hand clusters outline B, B, G, E. I find this passage very intense and effective, although it certainly offers multiple possibilities for musical interpretation. This last passage produces a high, glassy sound, which seems to rise beyond the din of the cotton mill. 


\section{Conclusion}

The main idea of this piece lies in two different characters, the machinery and the people.

In this work, Rzewski conveys three different abstract sounds through his compositional techniques: the sound of the machinery, the sound of people and the machinery together, and the sound of the people. This is a very eclectic work which requires a pianist with virtuosity, stamina both mentally and physically, an understanding of the jazz idiom, and knowledge of recent musical styles. The energy of this piece grabs the full attention of the audience, and the variety of musical language continues to entertain. Most of all, this piece seems to bring old memories into reality.

This is a very challenging and rewarding piece which will repay every pianist who chooses to learn it. It is also a very powerful work through which a pianist can demonstrate a full range of abilities on the instrument. This is evident in the fact that many pianists choose this work to perform in competition and recital. 


\title{
Chapter 5
}

\author{
Conclusion
}

"Down by the Riverside" and "Winnsboro Cotton Mill Blues" make great additions to a pianist's repertoire list; a combined performance of the two works ranges between fifteen and twenty minutes. They display a wide variety of characteristics exquisitely woven into the music: they are fun, serious, flamboyant, religious, bold, cool, and liberating.

These pieces require a skilled pianist who can successfully execute technically demanding passages which are disjunct and contain large intervals, can make cohesive transitions from one section to the next, can exhibit appropriate interpretation of jazz style, and can recognize the smallest fragments of the folk themes Rzewski manipulates. Despite the challenging elements of the pieces, Rzewski's piano compositions are some of the most popular contemporary works in the repertoire. In Joshua Kosman's article, "Improvising With a Pencil: the Piano Music of Frederic Rzewski," pianists Ursula Oppens and Thomas Schultz discuss Oppen's performance of People United Will Never Be Defeated!:

According to Oppens, it's practically designed to flatter a performer. "Frederic's music sounds fantastic," she says, "but it's so well written for the piano and it lies so comfortably under the hand, that it's never quite as hard as it sounds. The music is very grateful for the player. People always think you're better than you really are." Thomas Schultz, a San Francisco pianist who has performed many of Rzewski's works, concurs. "I've always thought it would be the perfect music for conservatory students," he says. "Anyone who can play Chopin or Liszt already has the necessary tools: big tremolos and trills, for instance. The music is very effective in that regard. It's less forbidding than Schoenberg or Boulez, and as far as I'm concerned it's every bit as forward-looking."

North American Ballads serves as a medium to carry on the legacy of America in the 1930s through pianists and their audiences. The stories these pieces hold immediately gain the attention of many people, including music critics, students, regular concert-goers, and non-music 
people. Many people outside the music field seem pleasantly surprised to find these familiar historical events referenced in the "high arts," as well as to recognize a tune they may have heard at some point in their life. Because Rzewski manifests elements of "high arts" in most of his piano compositions written in the 1970s, many pianists find it worthwhile to learn and study these pieces and perform them with great excitement.

"Down by the Riverside" and "Winnsboro Cotton Mill Blues" work well when performed together, as they each offer a very different ambience; yet the two ironically remain cohesive through similar musical elements. Furthermore, these two pieces give pianists the exciting opportunity to project great energy and refined style. And their audiences will retain their memories of these performances because they can relate to the stories the pieces tell. 


\section{Bibliography}

Beckman, Seth. "The Traditional and the Avant-Garde in Late Twentieth-Century Music: A Study of Three Piano Compositions by Frederic Rzewski." DMA diss., Ball State University, 1995.

Bell, Larry and Andrea Olmstead. "Musica Reservata in Frederic Rzewski's 'North American Ballads." The Musical Quarterly 72, No.4 (1986): 449-457.

http://www.jstor.org/stable/3113962.

Burge, David. Twentieth-Century Piano Music. New York: Schirmer Books, 1990.

Cahill, Sarah. "Some Piano Music by Frederic Rzewski." Contemporary Music Review 29, No.6 (Dec. 2010): 551-555.

Cornett-Murtada, Vanessa. "Quotation, Revolution, and American Culture: The Use of Folk Tunes and the Influence of Charles Ives in Frederic Rzewski's North American Ballads." DMA diss., The University of North Carolina at Greensboro, 2004.

Gann, Kyle. "Frederic Rzewski." Chamber Music 28, No.4 (Jul. 1, 2011): 22-23.

Gann, Kyle. American Music in the Twentieth Century. New York: Schirmer Books, 1997.

Gendron, Bernard. "Rzewski in New York (1971-1977)." Contemporary Music Review 29, No. 6 (December 2010): 557-574.

Gieseking, Walter and Karl Leimer. Piano Technique. New York: Dover Publication, Inc., 1972.

Gurewitsch, Matthew. "Maverick with a Message of Solidarity." New York Times, Apr. 27, 2008: p. 29.

Hamelin, Marc-André. The People United Will Never Be Defeated! Hyperion CDA 67077, 1999.

Hayashi, Kim. "The Keyboard Music of Frederic Anthony Rzewski with Special Emphasis on The North American Ballads" DMA diss., The University of Arizona, 1995.

Kim, Sujin. Understanding Rzewski's North American Ballads. Saarbrücken: Verlag Dr. Müller, 2011.

Kandell, Leslie. Review of concert performance by Frederic Rzewski (piano), ${ }^{6} \mathrm{New}$ York City: Frederic Rzewski" Making Music Series, Zankel Hall. American Record Guide: Music in Concert, September/October, 2008: 42-43.

Kodhn, Awn. "Creating Sounds for a Nonsensical World." Making Music Series, Zankel Hall. New York Times, May 3, 2008: 10. 
Lewis, Ronald Edwin. "The Solo Piano Music of Frederic Rzewski." D.M.A. diss., The University of Oklahoma, 1992.

Love, Andrew. "Improvising Their Future: Shamanic Hope in Ives, Schoenberg, Cage, Cardew, Rzewski, and Messiaen." Tempo 60, No. 237, July 2006, 24-32.

Newman, William S.. The Pianist's Problems. New York: Harper \& Brothers Publishers, 1950.

Paul, Robert C. "Improvisation in Twentieth-Century Solo Piano Repertoire, as Represented in Alvin Curran's First Piano Piece (1967) and Pieces Selected from Squares (1978) and Four North American Ballads (1978-1979), by Frederic Rzewski." DMA diss., The University of Miami, 1993.

Pollack, Howard Harvard Composers: Walter Piston and His Students, from Elliott Carter to Frederic Rzewski. N.J.: The Scarecrow Press, Inc., 1992.

Rockwell, John. All American Music: Composition in the Late Twentieth Century. New York: Alfred A. Knopf, 1983.

Rzewski, Frederic. Rzewski Plays Rzewski: Piano Works, 1975-1999. Nonesuch 79623-2, 2002.

Thompson, Ellen. Teaching and Understanding Contemporary Piano Music. San Diego: Kjos West, 1976.

Varela, Daniel. "A Question of Language': Frederic Rzewski in Conversation about Cornelius Cardew." Journal of Experimental Music Studies, March 17, 2004.

Waleson, Heidi "Anthems and Troubadours that Stirred Crowds to Protest." New York Times, Sep. 10, 1989: pp. 27, 40.

Whitehead, Annalee Schultz. "A Global Sampling of Piano Music from 1978 to 2005: A Recording Project.” DMA diss., The University of Maryland, 2011.

Woodard, Kathryn. ${ }^{6}$ The Pianist's Body at Work: Mediating Sound and Meaning in Frederic Rzewski's Winnsboro Cotton Mill Blues," in Sonic Mediations: body, sound, technology, ed. Carolyn Birdsall and Anthony Enns (UK: Cambridge Scholars, 2011), 127-139.

Zimmermann, Walter. Desert Plants: Conversations with 23 American Musicians. Vancouver: A.R.C., 1976, 303-319.

Zuraw, Michael. "From Ideology Into Sound: Frederic Rzewski's North American Ballads and Other Piano Music from the 1970s." DMA diss., 2003.

"Frederic Rzewski's $70^{\text {th }}$ Birthday Celebrated with Concerts at Gilmore Festival and Carnegie Hall." Nonesuch Online Journal. April 27, 2008.

http://www.nonesuch.com/journal/frederic-rzewskis-70th-birthday-celebrated-withconcerts-at-gilmore-festival-and-carnegie-ha 